\title{
Wintertime Arctic Ocean sea water properties and primary marine aerosol concentrations
}

\author{
J. Zábori ${ }^{1}$, R. Krejci ${ }^{1,5}$, A. M. L. Ekman ${ }^{2,7}$, E. M. Mårtensson ${ }^{1,3}$, J. Ström ${ }^{1}$, G. de Leeuw ${ }^{4,5,6}$, and E. D. Nilsson ${ }^{1}$ \\ ${ }^{1}$ Department of Applied Environmental Science, Stockholm University, 11418 Stockholm, Sweden \\ ${ }^{2}$ Department of Meteorology, Stockholm University, 11418 Stockholm, Sweden \\ ${ }^{3}$ Department of Earth Sciences, Uppsala University, 75236 Uppsala, Sweden \\ ${ }^{4}$ Meteorological Institute, Climate Change Unit, 00101 Helsinki, Finland \\ ${ }^{5}$ Department of Physics, University of Helsinki, 00014 Helsinki, Finland \\ ${ }^{6}$ TNO B\&O, NL-3508 TA Utrecht, The Netherlands \\ ${ }^{7}$ Bert Bolin Centre for Climate Research, Stockholm University, 11418 Stockholm, Sweden
}

Correspondence to: J. Zábori (julia.zabori@itm.su.se)

Received: 7 May 2012 - Published in Atmos. Chem. Phys. Discuss.: 29 June 2012

Revised: 30 September 2012 - Accepted: 17 October 2012 - Published: 7 November 2012

\begin{abstract}
Sea spray aerosols are an important part of the climate system through their direct and indirect effects. Due to the diminishing sea ice, the Arctic Ocean is one of the most rapidly changing sea spray aerosol source areas. However, the influence of these changes on primary particle production is not known.

In laboratory experiments we examined the influence of Arctic Ocean water temperature, salinity, and oxygen saturation on primary particle concentration characteristics. Sea water temperature was identified as the most important of these parameters. A strong decrease in sea spray aerosol production with increasing water temperature was observed for water temperatures between $-1^{\circ} \mathrm{C}$ and $9^{\circ} \mathrm{C}$. Aerosol number concentrations decreased from at least $1400 \mathrm{~cm}^{-3}$ to $350 \mathrm{~cm}^{-3}$. In general, the aerosol number size distribution exhibited a robust shape with one mode close to dry diameter $D_{\mathrm{p}} 0.2 \mu \mathrm{m}$ with approximately $45 \%$ of particles at smaller sizes. Changes in sea water temperature did not result in pronounced change of the shape of the aerosol size distribution, only in the magnitude of the concentrations. Our experiments indicate that changes in aerosol emissions are most likely linked to changes of the physical properties of sea water at low temperatures. The observed strong dependence of sea spray aerosol concentrations on sea water temperature, with a large fraction of the emitted particles in the typical cloud condensation nuclei size range, provide strong arguments for a more careful consideration of this effect in climate models.
\end{abstract}

\section{Introduction}

Sea spray aerosols (SSA) represent the largest natural aerosol source on Earth by mass flux. Sea salt emissions have been estimated to be on average $16600 \mathrm{Tgyr}^{-1}$ (Textor et al., 2006). SSA are aerosol particles produced at the ocean surface from breaking waves and consist of sea salt mixed with other species, in particular organic matter (de Leeuw et al., 2011). The aerosol particles have a substantial impact on the radiative balance of the Earth through scattering of incident solar radiation and as a source of cloud condensation nuclei $(\mathrm{CCN})$. Different model estimates of the global annual mean clear sky direct radiative forcing due to sea salt range between $-0.6 \mathrm{Wm}^{-2}$ and $-5.03 \mathrm{~W} \mathrm{~m}^{-2}$ (compilation of results in Ma et al., 2008). Clarke et al. (2006) reported that sea salt aerosols may account for between $5 \%$ and $90 \%$ of the $\mathrm{CCN}$ in the marine atmosphere. In recent years a number of studies have reported enrichment of organic matter in SSA; O'Dowd et al. (2004) reported that during plankton blooms in the North Atlantic Ocean, the organic fraction dominates the sub-micrometer aerosol mass, including water-insoluble and water-soluble organics. Using a cloud-parcel model, the same authors estimated an increase of cloud droplet concentrations between $15 \%$ and more than $100 \%$ due to the increase in organic matter. Ovadnevaite et al. (2011) stressed the importance of primary marine organic aerosol for the availability of CCN. Despite the hydrophobic properties of 
marine organics, a high activation efficiency, expressed as the ratio between $\mathrm{CCN}$ number and particle number with a diameter $>20 \mathrm{~nm}$, was found. However, since the physical and chemical properties of marine aerosols and their source intensity vary both in time and space, the magnitude of the impact of sea spray on the climate system is still not fully understood (Vignati et al., 2010; de Leeuw et al., 2011; Wang, 2007; Carslaw et al., 2010).

SSA are released to the atmosphere by air bubbles bursting on the ocean surface. For a natural ocean environment, air bubbles are generated from air entrainment during wave breaking (O'Dowd et al., 1997). Many different parameters influence the development of a bubble. Depending on the bubble diameter and the level of gas saturation in the water, bubbles tend to grow or dissolve (Slauenwhite and Johnson, 1999). The rise velocity of a bubble depends on the viscosity and the water density, but also varies with bubble size (Leifer et al., 2000). Coalescence between bubbles is thought to be inhibited or even prevented by ions in seawater (Slauenwhite and Johnson, 1999). The complexity of aerosol production due to bubble bursting has resulted in many different formulations of the SSA source functions, based on different methods, and a large uncertainty in the production fluxes (de Leeuw et al., 2011; Lewis and Schwartz, 2004). Parameterizations have been developed based on experimental studies relating parameters which influence ocean bubble formation to sea spray aerosol emissions. Sea spray production is highly dependent on wind speed, but water temperature $\left(T_{\mathrm{w}}\right)$, salinity, and oxygen saturation have also been identified as important properties controlling sea spray aerosol emissions (Nilsson et al., 2001; Mårtensson et al., 2003; Hultin et al., 2011, 2010).

The rapid environmental changes currently taking place in the Arctic region prompt a more thorough investigation of the influence of sea water temperature, salinity, and oxygen saturation on marine primary aerosol production over this region. The Arctic experiences a faster surface air temperature increase compared to the rest of the globe, a feature known as the polar amplification (ACIA, 2005). The high latitude warming rate during the last century is almost two times higher compared to the rest of the Northern Hemisphere (Bekryaev et al., 2010). This pattern must be a result of positive feedback processes that are especially effective at high latitudes, since the increase of anthropogenic greenhouse gas concentrations is more or less uniform over the globe (Miller et al., 2010; Lu and Cai, 2010). The key process behind the observed polar amplification is not yet well established, but the ice albedo feedback associated with a decrease in snow and ice-coverage has been the subject of a number of studies and is often touted as a key driver (Manabe and Stouffer, 1980; Holland and Bitz, 2003). However, Winton (2006) argued that the surface albedo feedback cannot be the dominating process for the Arctic amplification, and suggested instead that the most likely candidates are the net top of at- mosphere radiation flux forcing and the long wave radiation feedback.

No matter what causes the polar amplification, rapid changes have been observed in the Arctic during the last decades. The Arctic sea ice extent has decreased with $3.7 \% \pm$ $0.4 \%$ per decade based on satellite passive-microwave data observations between 1979 and 2006 (Parkinson and Cavalieri, 2008). For all seasons the observed trend was negative, but the largest trend was found in summer $(6.2 \%$ per decade). In addition, an acceleration of the ice retreat has been detected. From 1979 to 1996, the ice retreated at a rate of $2.2 \%$ per decade, whereas in following years the melting rate increased to $10.1 \%$ per decade (Comiso et al., 2008).

The changes do not only involve the seasonal first year sea ice. Perennial multilayer ice (ice that has survived the summer melt) has decreased at a rate of $7 \%$ per decade (19781998) (Johannessen et al., 1999). Moreover, the duration of the Arctic basin melt season has increased by 20 days during the last $30 \mathrm{yr}$ (Markus et al., 2009). All in all, there is an increasing body of evidence that an ice free summer Arctic can be a reality within the next 30-50 yr (Wang and Overland, 2009). A direct consequence of this sea ice retreat will be an increasing magnitude and importance of the marine aerosol source in the Arctic.

It is not only changes of the physical properties of sea ice that have been observed, but also altered physical and chemical conditions of the Arctic Ocean sea water, e.g., sea surface temperature, salinity, and organic content. Concurrent with the air temperature increase, a higher warming rate of the sea surface temperature in the Arctic compared to the global average has been noted during recent decades (Steele et al., 2008; Polyakov et al., 2007; Zhang, 2005). The higher water temperatures have resulted in changes of fresh water inflow into the Arctic Ocean and consequently in ocean salinity. Nuth et al. (2010) estimated a total volume loss of $9.71 \pm 0.55 \mathrm{~km}^{3} \mathrm{yr}^{-1}$ for Svalbard glaciers (excluding Austfonna and Kvitøya ice caps) during the last $40 \mathrm{yr}$, resulting in an estimated sea level rise of $0.026 \mathrm{~mm} \mathrm{yr}^{-1}$. The impact of the melt of the Greenland glaciers is estimated to be an order of magnitude larger (Lemke et al., 2007). The fresh water mixed with sea water will at least temporarily and locally lead to a decrease in salinity. This study focuses on physical changes of Arctic Ocean water and their impact on aerosol production. We recognize that changing environmental conditions will impact the fauna and flora in the Arctic Ocean (Wassmann and Reigstad, 2011; Tremblay et al., 2011) which will have both physical and chemical impacts on the Arctic Ocean water properties. As the flora changes, biological activity may be altered and therefore it is likely that changes in photosynthesis and respiration will occur as well. This photosynthesis/respiration change will impact on the oxygen saturation in the water, since the production of oxygen in the ocean by photosynthesis or a consumption of oxygen by respiration is given (Boyer et al., 1999; Kester and Pytkowicz, 1968; Falkner et al., 2005). The experiments 
by Hultin et al. (2011) suggested that diurnal changes in dissolved oxygen, caused by photosynthesis and respiration, modulated the sea spray formation. In addition, changes in the chemical composition of the water may arise as changes in photosynthesis and respiration alter the carbon content of the water. The additional consideration of changes in the chemistry of the water goes beyond the scope of this article, but this should be an important question for future studies.

In this work we test the hypothesis that primary marine sea spray aerosol emissions are affected by an on average higher water temperature, lower salinity, and a change in an unknown direction of the oxygen saturation (as a result of a change in biological activity). Using real Arctic sea water in laboratory experiments, we focus on analyzing the microphysical properties, including number concentration and number size distribution, of the aerosol particles emitted from the sea water surface by bubble bursting. To our knowledge, this is the first study of wintertime SSA production from Arctic Ocean water.

\section{Experiments}

\subsection{Experimental site}

Laboratory experiments using Arctic Ocean sea water were carried out at $\mathrm{Ny}$-Ålesund $\left(78^{\circ} 55^{\prime} \mathrm{N}, 11^{\circ} 56^{\prime} \mathrm{E}\right)$, Western Svalbard (Fig. 1a) in a marine laboratory during late Arctic winter conditions (from the 15 February to the 7 March 2010) and during late Arctic summer conditions (from the 24 August to the 7 September 2009). This paper presents results of the winter measurements, whereas Zábori et al. (2012) will compare summer and winter conditions. Sea water samples each of 1801 were collected at three different locations in the vicinity of Ny-Ålesund to cover possible differences between outer-fjord and inner-fjord conditions, including the potential influence of the Kongsbreen glacier (Fig. 1b). The samples were collected at the sea surface, using buckets either from a small motor boat or directly from the shore. When considering sea spray aerosol production, surface sea water samples should be the most relevant for characterizing the emissions from the ocean. However, a continuous supply of deep sea water ( $80 \mathrm{~m}$ below the sea surface) was also available in the laboratory. This water was used in the experiments as a controlled reference, given that water from this depth is more likely stable in terms of both biology and chemistry. It should be noted in this context that one part of the deep water continuous supply system was an inline filtration and UV-filter system (pore sizes $100 \mu \mathrm{m}$ and $20 \mu \mathrm{m}$ ), which could not be bypassed. This filtration system may potentially have affected the dissolved organic matter (DOM) concentration and composition of the deep seawater samples, both through removal of particulates and coagulation of dissolved surface active organic matter on the mechanical filters and through photochemical degradation of the DOM in the UV light fil-

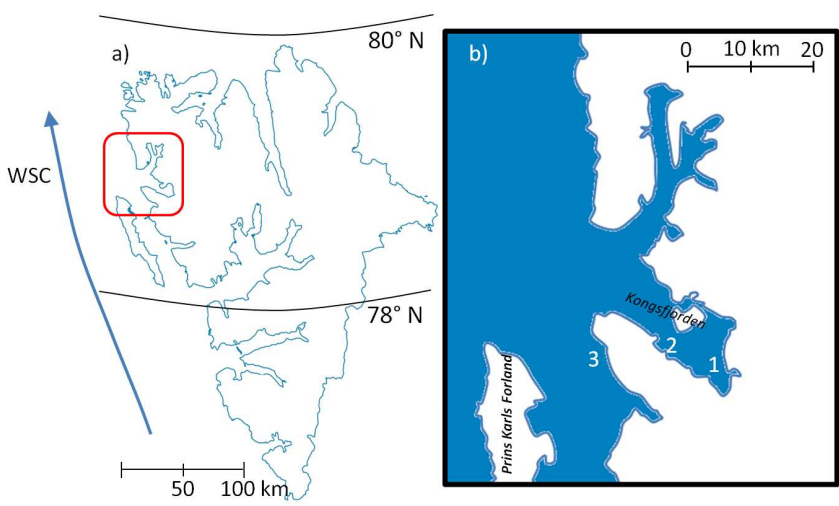

Fig. 1. (a) Overview map of the investigation area (marked red). Blue arrow indicates the direction of the West Spitsbergen Current (WSC). (b) Sampling locations. Point 1: close to the glacier, Point 2: marine laboratory with deep sea water inlet in Ny-Ålesund, Point 3: fjord mouth (outside of Kongsfjorden).

tration system (Mopper et al., 1991). Since the DOM chemistry was not quantified in any of the experiments and the filtration systems were not changed during the duration of the experiments, the potential effects of the filtration systems are assumed to be constant.

Sampling of the deep water sampling line supply took place on the 25 February and surface sea water close to the glacier was sampled on the 26 February. Surface sea water from the fjord mouth (referred to as "water from outside the fjord") was collected on five days: 21, 23 February and 1, 3 and 5 March.

\subsection{Environmental conditions}

The climate of Western Svalbard is highly influenced by the West Spitsbergen Current (WSC), the northernmost extension of the Norwegian Atlantic Current (Fig. 1a). The WSC with its relatively warm water accompanied by a relatively high salinity transports large amounts of heat deep into the Arctic Basin (Hop et al., 2006; Svendsen et al., 2002). This leads to a mostly ice-free ocean along the west coast of Svalbard and to relatively mild air temperatures compared to other locations at a similar latitude. The mean air temperature at $\mathrm{Ny}$-Ålesund from 1961 to 1990 was about $-15^{\circ} \mathrm{C}$ in February and about $4{ }^{\circ} \mathrm{C}$ in July (Svendsen et al., 2002). The average sea water temperature in Kongsfjorden has been estimated to be slightly above $0{ }^{\circ} \mathrm{C}$ and sea ice formation in winter is most pronounced close to the coast and in the inner parts of the fjord (Ito and Kudoh, 1997; Svendsen et al., 2002).

The water in Kongsfjorden is a mixture between Atlantic water brought by the WSC and Arctic basin shelf waters. This so-called "transformed Atlantic water" is characterized by water temperature $T_{\mathrm{w}}>1{ }^{\circ} \mathrm{C}$ and salinities above $34.7 \mathrm{psu}$ (Svendsen et al., 2002). In winter and autumn 
Table 1. Meteorological average conditions during the water sampling period (15 February to 7 March 2010) measured at Ny-Ålesund and provided by the Norwegian Meteorological Institute.

\begin{tabular}{lcccc}
\hline & Arithmetic mean $+/-$ standard deviation & Minimum value & Maximum value & Sum \\
\hline Air temperature $\left({ }^{\circ} \mathrm{C}\right)$ & $-14.4 \pm 4.1$ & -23.1 & -1.7 & - \\
Precipitation $(\mathrm{mm})$ & - & - & - & 21.5 \\
Air pressure $(\mathrm{hPa})$ & $1015.9 \pm 13.9$ & 967.4 & 1032.8 & - \\
Wind direction $\left({ }^{\circ}\right)$ & $156.0 \pm 54.2$ & - & - & - \\
Wind speed $\left(\mathrm{m} \mathrm{s}^{-1}\right)$ & $3.7 \pm 3.6$ & 0 & 19.9 & - \\
Cloud cover (octas) & $2.8 \pm 3.0$ & & 8 & - \\
\hline
\end{tabular}

so-called "local water" and "winter cooled water" (WCW) are formed in the fjord due to surface cooling and convection (Piehl Harms et al., 2007).

Meteorological average conditions for the period 15 February to 7 March are summarized in Table 1.

\subsection{Experimental setup}

The collected sea water was poured in a storage stainless steel 1901 tank from which it was pumped into a carefully sealed polyethylene bottle (Nalgene Labware) at a rate of $4.81 \mathrm{~min}^{-1}$ using an aquarium centrifugal pump (EHEIM). The water entered the bottle through a stainless steel nozzle with an inner diameter of $5 \mathrm{~mm}$ producing a water jet mimicking a falling wave crest which entrains air in sea water. This air subsequently breaks up into bubbles which burst at the water surface. The distance between the nozzle exit and the water surface was approximately $16 \mathrm{~cm}$. The water level in the polyethylene (PET) bottle was kept stable by a simple overflow system and the water volume remained constant at 101. Water flowing from the PET bottle was transferred back to the buffer storage tank through a PVC tube (more details about the experimental procedure can be found in Sect. 2.5). During one experiment the water flow was higher than $4.81 \mathrm{~min}^{-1}$ resulting from a lower water pump position (see end of Sect. 3.2).

Fuentes et al. (2010) compared different mechanisms for marine aerosol production in laboratory experiments with respect to their ability to reproduce a realistic oceanic bubble size spectrum. It was concluded that a plunging water jet was best at reproducing the shape of an oceanic bubble size spectra (cf. also Hultin et al., 2010). Hence, it is assumed that this method also results in the most realistic bubble-mediated aerosol size spectra (i.e., neglecting spume droplets produced from tearing of breaking waves).

To avoid any contamination by room air, air was pumped through an Ultra Filter (type H cartridge, MSA, Pittsburgh) into the PET bottle at flow rate of $121 \mathrm{~min}^{-1}$. Excess air of $11 \mathrm{~min}^{-1}$ was allowed to freely leave the top of the PET bottle through an opening of $5 \mathrm{~mm}$ in diameter. The quality of the particle-free air and the integrity of the whole setup were regularly checked by switching off the water jet, to confirm that the particle number concentration in the air space of the
PET bottle returned to zero. The sample air was collected from an air volume above the sea water in the PET bottle. The total sampling air flow was kept stable at $5.01 \mathrm{~min}^{-1}$ during all experiments. A scheme of the experimental setup is shown in Fig. 2 and parameters and physical characteristics of the bubble tank are listed in Table 2.

\subsection{Instrumentation}

The air sampling outlet of the PET bottle was connected through a $2 \mathrm{~m}$ long $1 / 4^{\prime \prime}$ stainless steel tube to the instrumentation that provided information about aerosol number concentration and size distribution. Based on the geometry of the aerosol sampling lines and associated inertial losses, the upper size limit which was reliably detected was estimated to be around $5 \mu \mathrm{m}$ in diameter $\left(D_{\mathrm{p}}\right)$.

The total aerosol number concentration was measured at $1 \mathrm{~Hz}$ for all particles with a $D_{\mathrm{p}}>0.01 \mu \mathrm{m}$ using a TSI model 3010 Condensation Particle Counter (CPC) and for all particles with a $D_{\mathrm{p}}>0.25 \mu \mathrm{m}$ using a GRIMM 1.109 Optical Particle Counter (OPC).

The size distribution for the size range $0.01 \mu \mathrm{m}<D_{\mathrm{p}}<$ $0.30 \mu \mathrm{m}$ was determined using a closed-loop sheath air custom-built differential mobility particle sizer (DMPS) equipped with a TSI 3010 CPC. One scan covering 15 size bins was completed in $2.5 \mathrm{~min}$. The aerosol size distribution in the range $0.25 \mu \mathrm{m}<D_{\mathrm{p}}<32 \mu \mathrm{m}$ was determined every $6 \mathrm{~s}$ with a GRIMM 1.109 Optical Particle Counter (OPC), sizing particles in 31 bins. The relative humidity of the sampled air was monitored in the sampling line prior to entering individual instruments with a Hygroclip SC04 hygrometer (Rotronic). The relative humidity near the sensing instruments was always lower than $10 \%$, which is mainly a result of the relative high temperature in the instrument payload. Whereas the aerosols were characterized as dry aerosol particles, the relative humidity conditions in the bottle where the bubbles were produced were significantly higher.

Water temperature, salinity, and oxygen saturation were continuously measured in the steel tank with a Stratos 2402 Cond and a Stratos 2402 Oxy from the Knick Elektronische Messgeräte $\mathrm{GmbH} \& \mathrm{Co}$.

The size distribution of air bubbles with bubble diameters $D_{b}$ between $30 \mu \mathrm{m}$ to $1140 \mu \mathrm{m}$, generated through an 


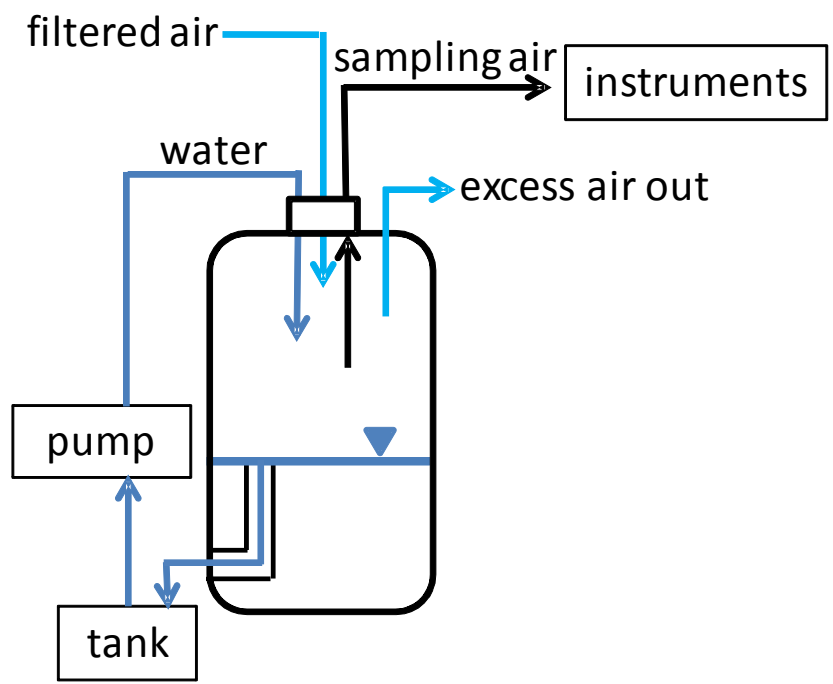

Fig. 2. Schematic picture of bubble bursting experimental setup. The tank was used as a buffer to recirculate the sea water sample trough the PET bottle, where SSA was produced by an impinging water jet. Darker blue lines represent water, and the triangle symbol indicates the water surface in the bottle.

impinging water jet comparable to the one used to produce aerosols in the PET bottle, was determined using an optical bubble spectrometer (TNO-mini BMS) in the stainless steel tank (Leifer et al., 2003). Similar to previous studies by, for example, Hultin et al. (2010) and Fuentes et al. (2010), the bubble spectrum was measured in a tank separate from the aerosol spectrum due to the size of the BMS and in order to avoid contamination.

\subsection{Experimental procedure}

Each one of the water samples of 1801 collected at the locations mentioned in Sect. 2.1 was divided into two equal subsamples. One subsample was used immediately in a bubble bursting experiment, whereas the other subsample was stored in a dark room at $4{ }^{\circ} \mathrm{C}$ air temperature (to minimize biological activity) for later experiments on the following day. The dark room was the only option to store the water at a relatively low temperature without freezing. Eliminating the risk of freezing was desired as a subsequent melting would be slow. A long melting time could result in a higher biological activity compared to the activity expected when storing the sample at $4^{\circ} \mathrm{C}$ in a dark room.

Two different types of experiments were performed, "warming experiments" where the water was slowly warmed up during the measurements and "cooling experiments" where the water was slowly cooled down. During warming experiments, the complete experimental setup was placed inside the marine laboratory where the water sample warmed up due to its exposure to room temperature. For the cooling experiments, the sea water sample was first placed indoors
Table 2. Physical characteristics of the bubble bottle.

\begin{tabular}{ll}
\hline Parameter & Characteristic number \\
\hline Water volume & 101 \\
Water flow rate & $4.81 \mathrm{~min}^{-1}$ \\
Distance nozzle to water surface & $16 \mathrm{~cm}$ \\
Inner diameter of stainless steel nozzle & $5 \mathrm{~mm}$ \\
Air sampling rate & $51 \mathrm{~min}^{-1}$ \\
Turn over time water & $2.1 \mathrm{~min}^{-1}$ \\
Turn over time air & $0.8 \mathrm{~min}$ \\
\hline
\end{tabular}

where it warmed up to approximately $6{ }^{\circ} \mathrm{C}$. Thereafter, the buffer tank was placed on a terrace outside the marine laboratory and exposed to ambient air temperatures around $-10^{\circ} \mathrm{C}$ to $-15^{\circ} \mathrm{C}$, while the rest of the setup and instrumentation remained indoors. The water from the buffer tank was transported into the marine laboratory through an open window slit. The tank was never exposed to direct sunlight.

The average warming and cooling rates were estimated to range between 1 and $2{ }^{\circ} \mathrm{Ch}^{-1}$. This warming rate is more than twice of that measured during a few daily warming events in the Arctic Ocean (up to $0.4^{\circ} \mathrm{Ch}^{-1}$, Eastwood et al., 2011). Given the high warming and cooling rates in the experiments, possible biologically-based long-term changes of water chemistry are most likely missed due to the short time frame of the measurements (approx. $6 \mathrm{~h}$ ).

\section{Results}

In this section we present the analysis of the influence of water temperature on the air bubble spectrum. Links between SSA microphysical properties (number concentration and size distribution) and the Arctic Ocean water temperature, salinity, and oxygen saturation were analyzed. Medians for the aerosol characteristics were calculated for $1{ }^{\circ} \mathrm{C}$ wide $T_{\mathrm{w}}$ bins. The total observational time per temperature bin varied between 8 and 73 min during warming experiments and between $6 \mathrm{~min}$ and close to $3 \mathrm{~h}$ during cooling experiments, respectively. Salinity bin widths were chosen as $1 \%$, with a smaller bin width for salinities lower than $28 \%$ as a result of limited data in this range (the lowest salinity measured was $26.5 \%$ and no salinity with $27.9 \%$ was recorded). The total measurement time for each salinity bin was between $20 \mathrm{~min}$ and close to $34 \mathrm{~h}$. Based on the relatively narrow oxygen saturation range between $72 \%$ and $83 \%$, associated aerosol data were not binned according to oxygen saturation. The typical duration of one experiment was approximately $6 \mathrm{~h}$.

\subsection{Air bubble spectra dependence on sea water temperature}

The investigation of water temperature effects on the air bubble spectra provides the background for the later discussion 
on the influence of water temperature on SSA properties. The influence of different salinities and oxygen saturations on the bubble development could not be sufficiently studied due to a limited number of bubble spectra measurements (varying between one and seven measurements per $T_{\mathrm{w}}$ bin). Within each temperature bin, the oxygen saturation and salinity values covered only a narrow data range.

All recorded bubble spectra were analyzed for the different water temperatures. In order to obtain a better comparison between the bubble spectra at different water temperatures, the bubble number size distributions were normalized to the size distribution at the highest water temperature. Within each size bin, no trend in the air bubble population with water temperature could be detected (data not shown).

All air bubble spectra were divided according to sampling location and the average concentrations per bubble diameter were calculated (Fig. 3). Figure 3 is based on 28 bubble spectra measurements in water sampled outside the fjord, nine measurements in water sampled close to the glacier and five measurements in deep sea water samples. All averaged bubble spectra show a similar shape, with one peak at $D_{\mathrm{b}} 70 \mu \mathrm{m}$ and one at $D_{\mathrm{b}} 100 \mu \mathrm{m}$ followed by a steady decrease of bubble number concentration with increasing bubble diameter.

A two-sample Kolmogorov-Smirnov test with a rejection of the null hypothesis at a $5 \%$ significance level was applied to the different bubble spectra. A significant difference was found between the deep and glacier water bubble size distributions for the first three size bins $\left(D_{\mathrm{b}} 30 \mu \mathrm{m}, 36 \mu \mathrm{m}\right.$ and $45 \mu \mathrm{m}$ ) and for bubble diameters of $84 \mu \mathrm{m}$ and $465 \mu \mathrm{m}$. A comparison of the bubble spectra resulting from water outside the fjord and the deep water showed significant differences at $D_{\mathrm{b}} 45 \mu \mathrm{m}$ and $D_{\mathrm{b}} 123 \mu \mathrm{m}$.

The shapes of the averaged bubble number size distributions, for the three different waters, were compared to typical bubble size distributions measured in the ocean to ensure that the preconditions of producing realistically aerosol spectra apply. Generally, bubble size distributions can be described as a power law function (Bowyer, 2001; Leifer and de Leeuw, 2006; Hultin et al., 2010) with the radius of the bubble $r$ :

$\mathrm{d} N / \mathrm{d} r=a r^{-\mathrm{b}}$.

For $0.1 \mathrm{~mm}<D_{\mathrm{b}}<1 \mathrm{~mm}$, the exponent $\mathrm{b}$ for bubble size distributions observed in the real ocean has been estimated to be close to 2 (see Hultin et al., 2010, for a compilation of measurements). Power law functions with the exponents of $b=2, b=1.7$ and $b=2.3$ are shown in Fig. 3 and suggest that the measured bubble spectra are comparable to bubble spectra occurring in the ocean, at least for $D_{\mathrm{b}}>0.1 \mathrm{~mm}$. In addition to the arithmetic mean values of the bubble spectra shown in Fig. 3, a median is shown as an example. For the bubble size range which follows the typical power law function of bubbles in the real ocean $\left(D_{\mathrm{b}}>0.1 \mathrm{~mm}\right)$, the arithmetic mean and the median of the bubble spectra are essentially not different. Even at sizes $D_{\mathrm{b}}<0.1 \mathrm{~mm}$, the difference

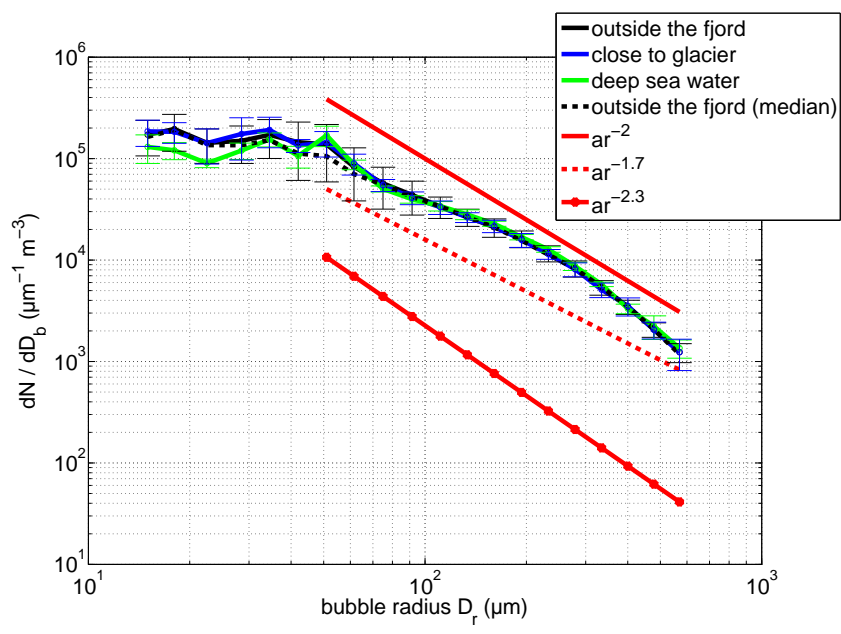

Fig. 3. Solid lines represent arithmetic means with standard deviations for bubble population distributions versus bubble diameter for different water sampling locations. The black dashed line shows as an example a median for comparison with the arithmetic mean. Averages are based on 28,9 , and 5 bubble spectra measurements from bubbles produced in water with its origin outside the fjord (black line), close to the glacier (blue line) and deep water (green line), respectively. Red lines represent power law functions $\mathrm{d} N / \mathrm{d} r=a r^{-b}$ with the bubble radius $r$ for $b=2, b=1.7$ and $b=2.3$.

is limited to at the most $30 \%$. For the other water types, the difference is smaller.

\subsection{Particle number concentration dependence on water temperature}

The particle number concentrations as a function of $T_{\mathrm{w}}$ between $-2{ }^{\circ} \mathrm{C}$ and $9{ }^{\circ} \mathrm{C}$ are shown for each experiment as a median for each temperature bin in Fig. 4. Figure 5 displays the medians of particle number concentrations per water temperature bin for the three different waters. While Fig. 4 presents information about the variability of the particle number concentration generated by one water type, Fig. 5 allows for a comparison between the different waters. In each case two experiments were conducted with deep water and water sampled close to the glacier and six experiments were conducted with water from the fjord mouth. For the experiments based on water close to the glacier and deep sea water, the two experiments were conducted with water sampled at one single time, but half of the water was stored before starting the second experiment. For water outside the fjord, four experiments were conducted with two water samples collected at the same time. For the other experiments with water outside the fjord, no water sampled at the same time was used twice. Only data from warming experiments are considered, and only data for the most common salinities between $34 \%$ and $35 \%$ o (representing more than $33 \mathrm{~h}$ of measurements) were used in the analysis, in order to exclude any possible influence of salinity. The typical salinity 

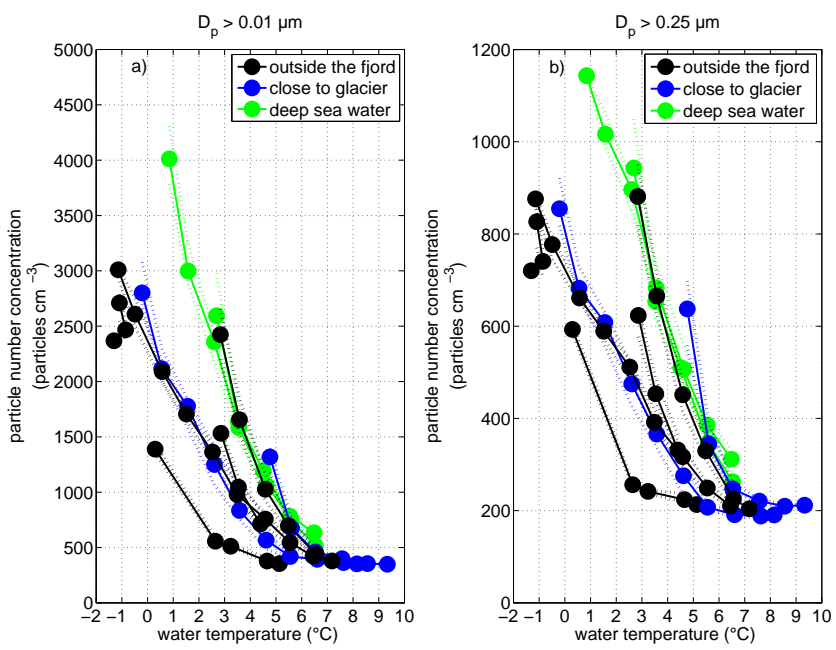

Fig. 4. Medians of particle number concentration for distinct water temperature bins and each experiment. Dashed lines represent 25th and 75 th percentiles. The salinity was between 34.3 and $34.4 \%$ o for the sampled water close to the glacier, 34.4 to $34.7 \%$ o for the deep water and 34.1 to $35.0 \%$ o for experiments which were conducted using sea water from outside the fjord. (a) Measurements for particles with $D_{\mathrm{p}}>0.01 \mu \mathrm{m}$. (b) Measurements for particles with $D_{\mathrm{p}}>0.25 \mu \mathrm{m}$. Note the different scales.

of WCW occurring in Kongsfjorden is approximately between $34 \%$ and $35 \%$ (Piehl Harms et al., 2007). For the total particle number concentration, particle sizes are analyzed separately for $D_{\mathrm{p}}>0.01 \mu \mathrm{m}$ and $D_{\mathrm{p}}>0.25 \mu \mathrm{m}$ based on the cut-off sizes of CPC and OPC used for the measurements.

Generally, particle number concentrations decrease with increasing water temperature. This effect is clearest for the lowest water temperatures, while for higher temperatures the decrease levels off. The magnitude of this effect is different for the different water samples (Fig. 4). Quantitatively, the surface water from the fjord mouth spans a wider range of particle number concentrations (up to a factor of 5) for a given temperature compared to particle concentrations resulting from deep sea water and water close to the glacier. The water sampled close to the glacier results in one curve close to the center of the data range and one in the upper range from the fjord mouth water, while both curves resulting from deep water are in the upper range (Fig. 4). We cannot say, however, if additional experiments would have shown a larger variation for the glacier and deep water, as well. For the glacier water, where we have two experiments, the temperature range shows a difference in particle number concentrations of up to a factor of about 2-3 (for $T_{\mathrm{w}}$ between 4 and $5^{\circ} \mathrm{C}$ and $\left.D_{\mathrm{p}}>0.01 \mu \mathrm{m}\right)$. At sea water temperatures of around $6{ }^{\circ} \mathrm{C}-7^{\circ} \mathrm{C}$, the particle number concentrations generally converge to around 400 particles $\mathrm{cm}^{-3}\left(D_{\mathrm{p}}>0.01 \mu \mathrm{m}\right)$ and 200 particles $\mathrm{cm}^{-3}\left(D_{\mathrm{p}}>0.25 \mu \mathrm{m}\right)$ (Fig. $4 \mathrm{a}, \mathrm{b}$ ).

As previously described, half of the sea water sample was used on the same day the sample was collected and the sec-
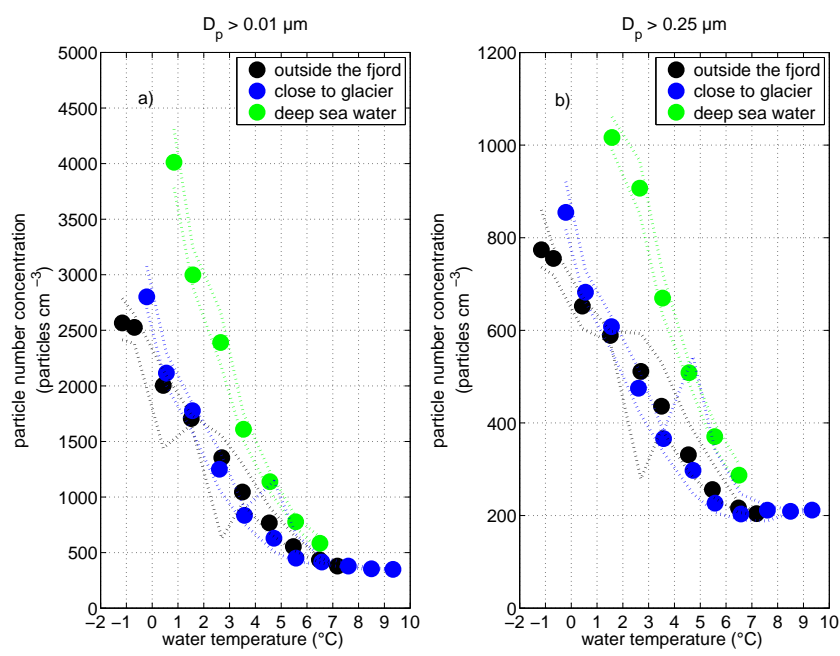

Fig. 5. Medians of the particle number concentration as a function of water temperature for different sampling locations. Dashed lines represent the 25th and 75th percentiles. (a) Measurements for particles with $D_{\mathrm{p}}>0.01 \mu \mathrm{m}$. (b) Measurements for particles with $D_{\mathrm{p}}>0.25 \mu \mathrm{m}$. Note the different scales.

ond half was used in an identical experiment the subsequent day (though not always covering exactly the same temperature range). The experiments from the first day were compared with the experiments from the second day for the different types of water. The smallest difference was obtained for deep sea water (not shown), where the particle number concentrations differed by less than $10 \%\left(D_{\mathrm{p}}>0.01 \mu \mathrm{m}\right)$ and around $7 \%\left(D_{\mathrm{p}}>0.25 \mu \mathrm{m}\right)$. For the water sample collected close to the glacier, the particle number concentrations were $44 \%$ lower $\left(D_{\mathrm{p}}>0.01 \mu \mathrm{m}\right)$ in the experiment conducted the first day compared to the second day, and $51 \%$ lower for particles with a $D_{\mathrm{p}}>0.25 \mu \mathrm{m}$. For the surface water from the fjord mouth, the particle number concentration for the first experiment was on average $97 \%$ and $68 \%$ lower for particles $D_{\mathrm{p}}>0.01 \mu \mathrm{m}$ and particles $D_{\mathrm{p}}>0.25 \mu \mathrm{m}$, respectively. Comparing the other two experiments replicated with sea water outside Kongsfjorden resulted in differences around $14 \%$ for both particles with $D_{\mathrm{p}}>0.01 \mu \mathrm{m}$ and particles with $D_{\mathrm{p}}>0.25 \mu \mathrm{m}$.

Medians of the particle number concentrations for each water temperature bin for the distinct water types are shown in Fig. 5. The median of the particle number concentrations for the different water types converge at $T_{\mathrm{w}}>6^{\circ} \mathrm{C}$. Figure 5 indicates that below $T_{\mathrm{w}} 7^{\circ} \mathrm{C}$, the median particle number concentrations (for particles with a $D_{\mathrm{p}}>0.01 \mu \mathrm{m}$ and particles $D_{\mathrm{p}}>0.25 \mu \mathrm{m}$ ) produced from the water sampled close to the glacier and out of the fjord do not differ significantly, but the median particle number concentrations from deep sea water are significantly higher. A twosample Kolmogorov-Smirnov test applied to the data shows 


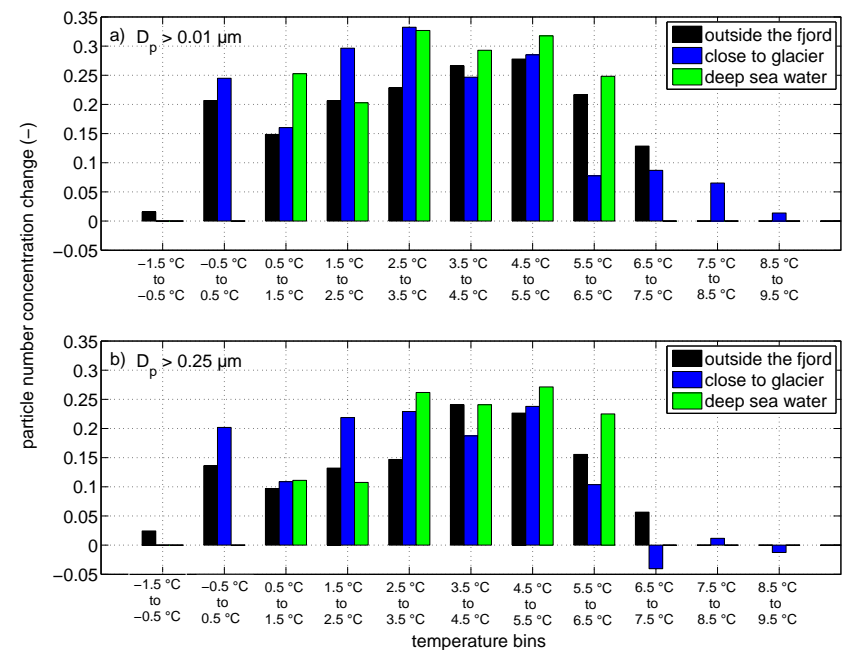

Fig. 6. Medians of the relative change in particle number concentration from one temperature bin to the previous one. Numbers on the $\mathrm{x}$-axis represent the middle of the two temperature bins for which the particle number concentration change was calculated. (a) Measurements for particles with $D_{\mathrm{p}}>0.01 \mu \mathrm{m}$. (b) Measurements for particles with $D_{\mathrm{p}}>0.25 \mu \mathrm{m}$.

a significant difference for all waters and temperature bins (significance level of $5 \%$ ).

The relative change in aerosol number density from one temperature bin to the next one shows a maximum at $T_{\mathrm{w}}$ between $2{ }^{\circ} \mathrm{C}$ and $5^{\circ} \mathrm{C}$ (Fig. 6). At this temperature range, the decrease of $T_{\mathrm{w}}$ by one degree results in an increased aerosol concentration of the order of $22 \%$ to $33 \%$ for particles with $D_{\mathrm{p}}>0.01 \mu \mathrm{m}$ and between $14 \%$ to $27 \%$ for particles with $D_{\mathrm{p}}>0.25 \mu \mathrm{m}$, depending on the type of water. At higher and lower sea water temperatures the rate of change in the aerosol concentration is lower. This type of pattern is observed for all three types of water (Fig. 6), but it is less pronounced for the glacier water.

To test whether the increase in aerosol concentrations with decreasing water temperature is a robust feature and to exclude possible unknown experimental artifacts, the whole procedure was performed in a reversed manner. The second half of the sample was in two cases slowly warmed up in darkness to $2^{\circ} \mathrm{C}$ and $5^{\circ} \mathrm{C}$, respectively. The bubble bursting experiment was then carried out, while the tank with sea water was placed on a terrace outside the marine laboratory and the sample water was slowly cooled down by the ambient outside air temperature (approx. $-12^{\circ} \mathrm{C}$ ). In Fig. 7 the warming experiments (referred to as $\mathrm{W} 1$ and W2) with their associated cooling experiments (referred to as $\mathrm{C} 1$ and $\mathrm{C} 2$ ) are presented. It is clear that cooling of the sea water from $2^{\circ} \mathrm{C}(\mathrm{C} 1)$ and $5^{\circ} \mathrm{C}(\mathrm{C} 2)$, respectively to subzero temperatures resulted in increased particle number concentrations for both cases, i.e., a mirroring of the warming experiments. For the warming/cooling experiment W2/C2, the change in aerosol emissions with sea water tempera-
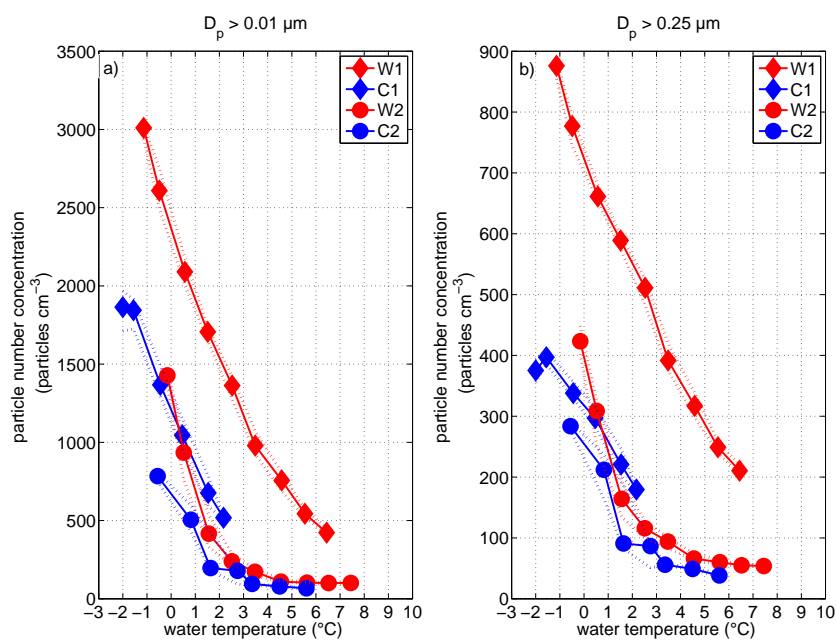

Fig. 7. Comparison of warming experiments with their related cooling experiments using sea water from outside the fjord $(\mathrm{W} 1=$ warming experiment $1, \mathrm{C} 1=$ cooling experiment 1 , $\mathrm{W} 2=$ warming experiment $2, \mathrm{C} 2=$ cooling experiment 2 ). The same markers indicate two related types of water. Dashed lines are the 25th and 75th percentiles. Red solid lines represent experiments with increasing water temperature and blue solid lines experiments with decreasing water temperature. (a) Medians of particle number concentration with $D_{\mathrm{p}}>0.01 \mu \mathrm{m}$. (b) Medians of particle number concentration with $D_{\mathrm{p}}>0.25 \mu \mathrm{m}$.

ture shows a similar trend of comparable magnitude. The aerosol number density for $D_{\mathrm{p}}>0.01 \mu \mathrm{m}$ changed by $87 \%$ (C2) and $89 \%(\mathrm{~W} 2)$ for a change between $T_{\mathrm{W}}=0.5^{\circ} \mathrm{C}$ and $T_{\mathrm{w}}=5.6^{\circ} \mathrm{C}$. The associated accumulation mode aerosol density for $D_{\mathrm{p}}>0.25 \mu \mathrm{m}$ changed by $82 \%$ (C2) and $81 \%$ (W2), respectively. The other set of warming/cooling experiments (W1/C1) displayed a similar trend, but with much larger difference in magnitude between the cooling and warming experiments. The number particle concentration change was $51 \%$ for $\mathrm{C} 1$ and $35 \%$ for W1 with $D_{\mathrm{p}}>0.01 \mu \mathrm{m}$ (from $T_{\mathrm{w}}=-0.5^{\circ} \mathrm{C}$ to $T_{\mathrm{w}}=1.5^{\circ} \mathrm{C}$ ). A number increase of $35 \%$ (C1) and a decrease of $24 \%$ (W1) were calculated for particles with $D_{\mathrm{p}}>0.25 \mu \mathrm{m}$.

Comparing the absolute particle number concentrations can be misleading, since it depends on the experimental setup (the position of the water pump with respect to the water level in the tank and the PET bottle and the water flow itself). Different water pump heights will result in different intensities of the water jet impacting on the water surface (different water flows) and so in different efficiencies of air entrainment into the sea water. This change in entrainment will influence the magnitude of air bubble formation in sea water. This is illustrated with the W1 experiment (Fig. 7) where the water pump was situated in a lower position compared to the other experiments, which most likely resulted in a larger water flow. 
Table 3. Salinity bins and the days from which the median total particle number concentration for the different water temperature bins was calculated.

\begin{tabular}{ll}
\hline Salinity bin $(\%)$ & Day of experiment \\
\hline 26 to 27 & 7 Mar \\
27 to 28 & 7 Mar \\
32 to 33 & 5 and 6 Mar \\
33 to 34 & 5 and 6 Mar \\
34 to 35 & $21,22,23,24,25,26,27$ Feb and 1,5 and 6 Mar \\
35 to 36 & $21,22,23,24$ Feb and 1,5 and 6 Mar \\
\hline
\end{tabular}

\subsection{Particle number concentration dependence on salinity}

Besides water temperature, changes in salinity are expected to have a pronounced effect on the aerosol concentration resulting from the bubble bursting process. In the following subsection, results from experiments covering a salinity range between $26 \%$ and $36 \%$ and measurement times per salinity bin between $20 \mathrm{~min}$ and $33 \mathrm{~h}$ are presented. Differences in salinity result from

- different sampling locations,

- formation of ice slush at subzero temperatures, and

- adding fresh glacier ice to the water sample.

Fresh glacier ice was collected close to Ny-Ålesund and added to a water sample in an attempt to investigate the effect of melted glacier water on aerosol emissions from sea water. Table 3 displays the different salinities and the days the experiments were conducted. On the evening of 6 March, fresh glacier ice was added to the water sample and the salinity decreased below $28 \%$ the following day.

On 5 March water was sampled outside the fjord and the salinity was typically expected to be above $34 \%$. However, since the sea was almost completely frozen, except at some spots from where the sampling took place, a high amount of ice slush with a lower salinity was also collected from the ocean surface, leading to relatively low salinities in the sample, i.e., between $32 \%$ and $34 \%$. For all sampling sites, the sea water samples often froze during the transport to the marine laboratory. Therefore, at water temperatures between zero degrees and the freezing point of sea water (about $-1.5^{\circ} \mathrm{C}$ to $-1.9^{\circ} \mathrm{C}$ depending on salinity) salinities higher than $34 \%$ were measured as a result of a not yet completely melted sample in the storage tank.

Measured median, 25- and 75-percentile particle number concentrations as a function of water temperature and salinity are shown in Fig. 8. For $T_{\mathrm{w}}$ from $-2{ }^{\circ} \mathrm{C}$ to $+2{ }^{\circ} \mathrm{C}$, the median particle number concentration $\left(D_{\mathrm{p}}>0.01 \mu \mathrm{m}\right) \mathrm{de}-$ creases with salinity for each temperature bin, but the variability of particle number concentration within one water temperature bin is, with an interquartile range up to more
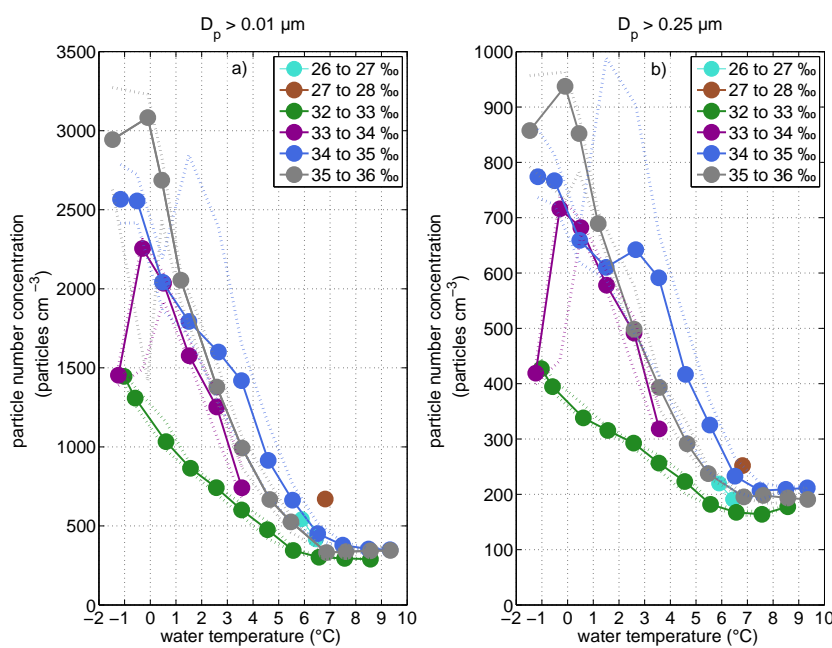

Fig. 8. Median particle number concentration dependence of salinity for different water temperature bins. Dashed lines represent 25th and 75th percentiles. (a) Medians of total particle number concentrations for particles with a $D_{\mathrm{p}}>0.01 \mu \mathrm{m}$. (b) Medians of total particle number concentrations for particles with a $D_{\mathrm{p}}>0.25 \mu \mathrm{m}$.

than $1000 \mathrm{~cm}^{-3}$, rather high. As discussed earlier, the aerosol concentration can vary substantially among individual samples for the same salinity and temperature. The low variability in measured particle number concentrations for salinities between $32 \%$ and $33 \%$ is likely a result of the small number of experiments conducted for this salinity range $(n=1)$. For $T_{\mathrm{w}}$ from $2{ }^{\circ} \mathrm{C}$ to $4{ }^{\circ} \mathrm{C}$, the median particle number concentration $\left(D_{\mathrm{p}}>0.01 \mu \mathrm{m}\right)$ is highest for salinities between $34 \%$ and $35 \%$ and then decreases with decreasing salinity. For higher water temperatures, there is no clear trend of the median particle number concentration with salinity. A similar pattern can be observed for the measurements of particles with $D_{\mathrm{p}}>0.25 \mu \mathrm{m}$.

Since the variability of the measured particle number concentration for a certain salinity within one temperature bin is relatively large, especially for salinities between $33 \%$ and $36 \%$, a two-sample Kolmogorov-Smirnov test was applied to the data. A test was conducted to determine if the particle number concentration of a given salinity within one $T_{\mathrm{w}}$ bin was significantly lower compared to the particle number concentration resulting from water having the adjacent higher salinity range. The test was applied for particle number concentrations with $D_{\mathrm{p}}>0.01 \mu \mathrm{m}$ and $D_{\mathrm{p}}>0.25 \mu \mathrm{m}$. Figure 9 shows, that for particles with a $D_{\mathrm{p}}>0.01 \mu \mathrm{m}$, the hypothesis was fulfilled for salinities between $32 \%$ to $34 \%$ for the whole temperature range and that it was rejected for the salinity range between $34 \% 0$ and $35 \%$ for $T_{\mathrm{w}}>2{ }^{\circ} \mathrm{C}$. The test results differ only slightly for the particles with a $D_{\mathrm{p}}>0.25 \mu \mathrm{m}$.

Only in the range of $T_{\mathrm{w}}$ between -2 and $-1{ }^{\circ} \mathrm{C}$ and $T_{\mathrm{w}}$ between 0 and $1{ }^{\circ} \mathrm{C}$ were there significantly lower particle 


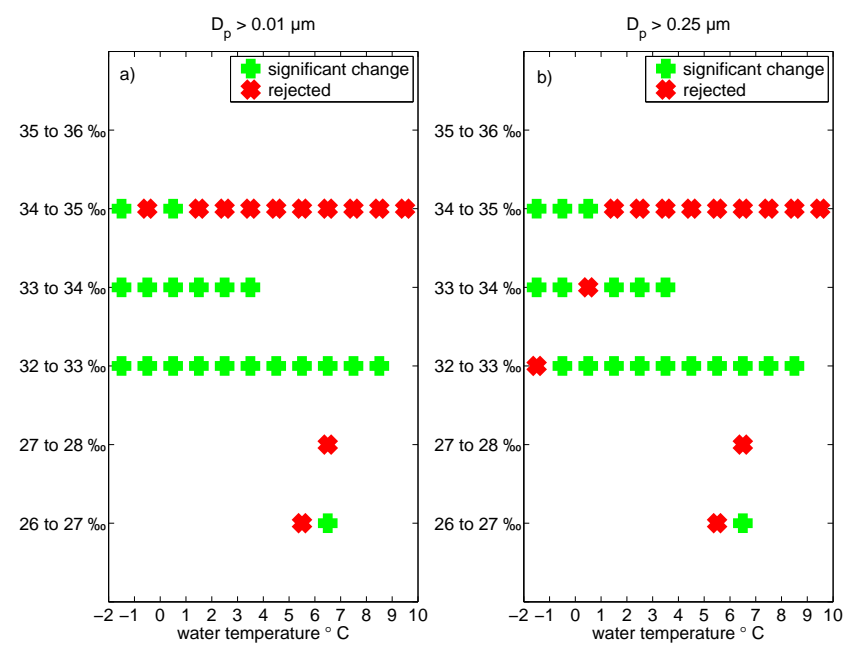

Fig. 9. Green markers show significantly lower particle number concentrations for the salinity to the left of the markers compared to the adjacent higher salinity bin by applying the two-sample Kolmogorov-Smirnov test. The red markers show a rejection of the hypothesis. (a) $D_{\mathrm{p}}>0.01 \mu \mathrm{m}$ (b) $D_{\mathrm{p}}>0.25 \mu \mathrm{m}$.

number concentrations (for $D_{\mathrm{p}}>0.01 \mu \mathrm{m}$ ) between one salinity bin and the adjacent higher salinity bin, indicating that the particle number concentration followed a trend with salinity. For particles with $D_{\mathrm{p}}>0.25 \mu \mathrm{m}$ this was only observed for $T_{\mathrm{w}}$ between -1 and $0{ }^{\circ} \mathrm{C}$ (Fig. 9).

\subsection{Particle number concentration dependence on oxygen saturation}

The oxygen saturation in the experiments varied over a narrow range between $72 \%$ and $83 \%$ during the whole winter experiment, which made it difficult to assess a possible influence of oxygen saturation on sea spray aerosol emissions. Taking two rather different cases with water temperature ranges between $5{ }^{\circ} \mathrm{C}$ and $6{ }^{\circ} \mathrm{C}$ and $1{ }^{\circ} \mathrm{C}$ and $2{ }^{\circ} \mathrm{C}$ and similar salinities between $34 \%$ and $35 \%$; a dependence of oxygen saturation on particle number concentration for particles with a $D_{\mathrm{p}}>0.01 \mu \mathrm{m}$ and $D_{\mathrm{p}}>0.25 \mu \mathrm{m}$ was not observed.

\subsection{Influence of salinity on the particle number size distribution}

The influence of salinity on the shape of the particle number size distribution was examined for waters having a water temperature between $6^{\circ} \mathrm{C}$ and $7^{\circ} \mathrm{C}$. This temperature range was chosen as the measurements in this interval covered a broad range of salinities (between 26\%o and 36\%o). Median number size distributions for the lowermost measured salinities (between 26\%o and 28\%o) were compared to the size distribution of the highest measured salinities (between
$35 \%$ and $36 \%$ ) and to the most common salinity of $34 \%$ o to $35 \%$ (not shown).

All size distributions showed local maxima and minima at the same sizes and no influence of the examined salinity range on the shape of the size distribution was detected. No salinity dependent trend in total particle number concentration for sub-micron and super-micron particles was observed.

\subsection{Influence of water temperature on the particle number size distribution}

The impact of the water temperature on the magnitude and shape of the aerosol number size distribution was examined using data from measurements performed on 3 and 4 March 2010. The changes in median aerosol size distribution were studied during a warming experiment from $T_{\mathrm{w}}-1^{\circ} \mathrm{C}$ to $5^{\circ} \mathrm{C}$ (Fig. 10) and the corresponding cooling experiment from $T_{\mathrm{w}}$ $4{ }^{\circ} \mathrm{C}$ to $-2^{\circ} \mathrm{C}$ (Fig. 11). These two experiments cover the most relevant sea water temperature range and can be directly compared to each other as they were made with the same water sample. Aerosol size distributions from other experiments were analyzed in a similar way and the result from these experiments are well represented by the example experiments from 3 and 4 March (Figs. 10 and 11). For every $1{ }^{\circ} \mathrm{C}$ sea water temperature bin, the median aerosol size distribution is based on 8-18 (individual) DMPS size distributions and 150-400 (size) distributions measured by the OPC.

A comparison between the number size distributions resulting from warming (Fig. 10a) and cooling (Fig. 11a) shows that for all size distributions, independent of the associated water temperature, there are two local maxima at $180 \mathrm{~nm}$ and $570 \mathrm{~nm}$. The most prominent feature is the robustness of the aerosol size distribution shape. Changes related to sea water temperature are pronounced almost only in the magnitude of the aerosol size distribution. The relative proportion between both modes at $180 \mathrm{~nm}$ and $570 \mathrm{~nm}$ is however changing slightly depending on sea water temperature. During both the warming and the cooling experiment (Figs. 10a and 11a), for water temperatures up to $3{ }^{\circ} \mathrm{C}$, the maximum at $180 \mathrm{~nm}$ is most distinct. For sea water temperatures greater than $3{ }^{\circ} \mathrm{C}$, the peak at about $570 \mathrm{~nm}$ is more pronounced. In addition, a smaller local maximum at around $2 \mu \mathrm{m}$ becomes more important at higher sea water temperatures. Median aerosol volume size distributions for the same warming and cooling experiments were calculated for the different temperature ranges and are shown in Figs. 10b and 11b. A maximum of the total aerosol volume within the measured size range was observed at dry diameters between $3 \mu \mathrm{m}$ and $4 \mu \mathrm{m}$. Below $2 \mu \mathrm{m}$ size, the aerosol volume is decreasing with increasing sea water temperature in a similar pattern as the aerosol number size distribution.

A comparison between the median number size distributions calculated for the three different kinds of sampled water (outside the fjord, close to the glacier and the deep water sample) for $T_{\mathrm{w}}=2^{\circ} \mathrm{C}-4{ }^{\circ} \mathrm{C}$ shows a consistency for all local 

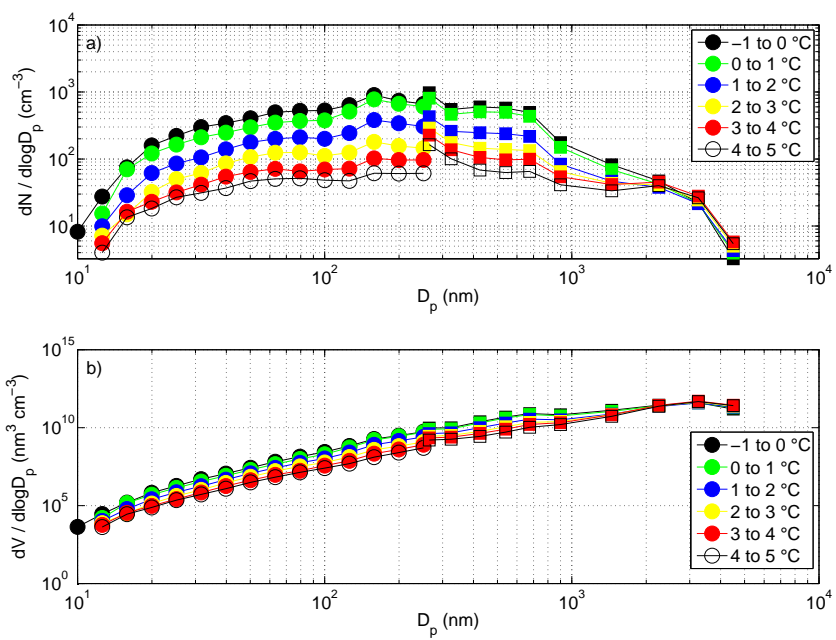

Fig. 10. (a) Median particle number size distributions for different water temperatures. (b) Particle volume size distributions for different water temperatures. The warming experiment was conducted with water sampled outside the fjord on 3 March 2010. The part of the size distribution measured by DMPS is marked with circles, whereas the part measured by OPC is marked with squares. Only every second bin data point is shown for clarity.

maxima and minima (Fig. 12a). Medians were calculated using between 24-66 size distributions from DMPS measurements and between 610-1690 size distributions from the OPC measurements. Peaks in the size distributions are found at about $180 \mathrm{~nm}$, between $375 \mathrm{~nm}$ and $615 \mathrm{~nm}$, and around $1.8 \mu \mathrm{m}$. The peak at $180 \mathrm{~nm}$ and the peak between $375 \mathrm{~nm}$ and $615 \mathrm{~nm}$ have the same magnitude for each size distribution of the different types of water, whereas the mode at $1.8 \mu \mathrm{m}$ is much lower in magnitude for all size distributions. The slight difference in the magnitude of the peak between the different types of water may result from the large variability in particle number concentration between the experiments (Fig. 4). The corresponding volume size distributions for respective types of water (Fig. 12b) show a peak at dry diameters between $3 \mu \mathrm{m}$ and $4 \mu \mathrm{m}$.

\section{Discussion}

The hypothesis, that primary marine sea spray aerosol emissions are affected by changed physical properties of the Arctic Ocean, is partly confirmed and partly repudiated. The hypothesis was repudiated for a change in oxygen saturation between $72 \%$ and $83 \%$ and could not be confirmed for a change of salinity between $36 \%$ and $26 \%$ (for a wide range of different water temperatures). The hypothesis that an increase in average water temperature impacts on SSA emissions was on the other hand confirmed. The results which led to these conclusions will be discussed separately for the different tested parameters in the following sections, beginning
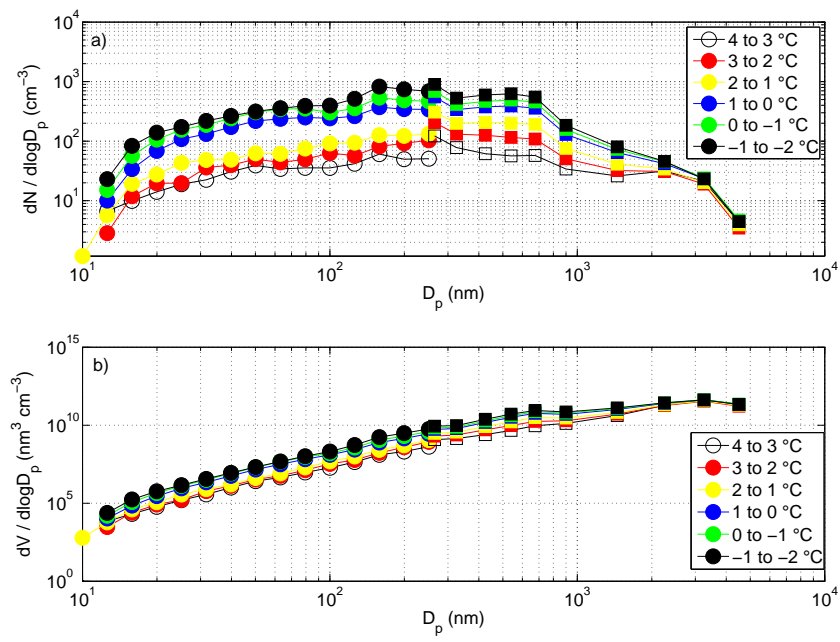

Fig. 11. (a) Median particle number size distributions for different water temperatures. (b) Particle volume size distributions for different water temperatures. The cooling experiment was conducted with water which was sampled outside the fjord 3 March 2010 and then stored in a dark room with an air temperature of $4{ }^{\circ} \mathrm{C}$. The part of the size distribution measured by DMPS is marked with circles, whereas the part measured by OPC is marked with squares. Only every second bin data point is shown for clarity.

with a discussion of the results regarding how water temperature influenced the air bubble spectra. An influence of water temperature on air bubble spectra was not included in the hypothesis, but was expected to give an explanation for possible observed relationships between the tested physical properties and the SSA emissions.

\subsection{Effect of sea water temperature on air bubble number spectra}

The observed bubble spectra between about $100 \mu \mathrm{m}<D_{\mathrm{b}}<$ $1140 \mu \mathrm{m}$ was shown to be comparable to bubble spectra measured during other in-situ experiments under non-laboratory conditions. Consequently, the generated SSA should mimic the bubble driven flux as far as our understanding permits. However, for the experiments presented here, no dependence of the bubble number size distribution on sea water temperature was detected for bubbles with $30 \mu \mathrm{m}<D_{\mathrm{b}}<1140 \mu \mathrm{m}$. This undetected impact of sea water temperature on the bubble spectra is somewhat unexpected since several previous studies have detected such an influence, both in fresh water and in sea water (Hwang et al., 1991; Thorpe et al., 1992; Slauenwhite and Johnson, 1999). Hwang et al. (1991), using an impinging water jet, showed that the entrainment depth of bubbles with a diameter of $0.1 \mathrm{~mm}$ increased with increasing water temperatures from $11^{\circ} \mathrm{C}$ to about $19^{\circ} \mathrm{C}$ and remained at a plateau value for higher water temperatures.

Thorpe et al. (1992) pointed out that when water temperature increases, the molecular diffusivity also increases, but 

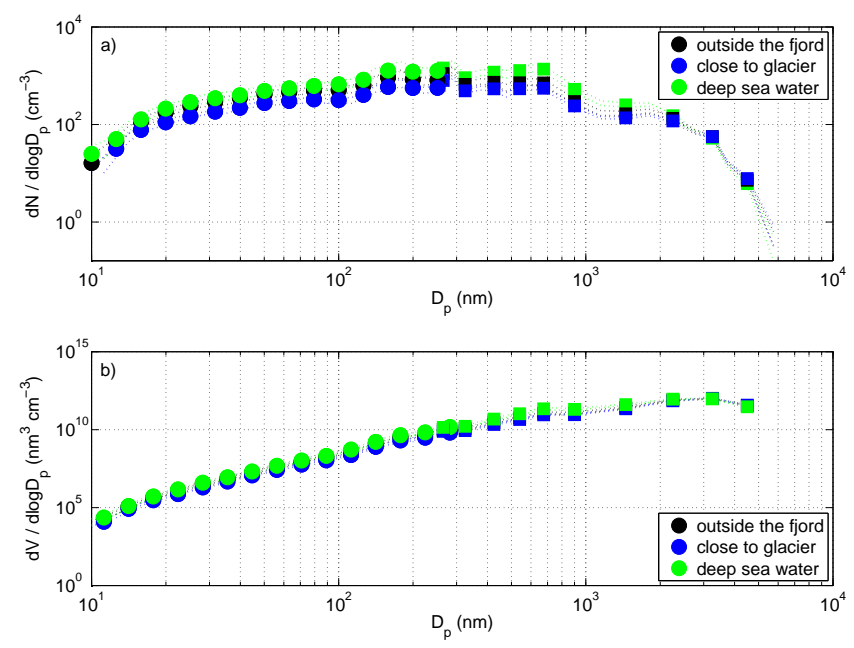

Fig. 12. (a) Comparison of median particle number size distributions for different sea water types. (b) Comparison of median particle volume size distributions. Dashed lines represent the 25 th and 75th percentiles. The part of the size distribution measured by DMPS is marked with circles, whereas the part measured by OPC is marked with squares. Only every second data point is shown for clarity.

the viscosity and the solubility of oxygen and nitrogen decrease. The decrease in viscosity for higher water temperatures results in a higher bubble rise velocity. At the same time, the reduced solubility of oxygen and nitrogen with increasing water temperature leads to an increase of bubble numbers, but this effect is to some extent buffered by the increase in diffusivity. As a net effect, the numerical model by Thorpe et al. (1992) showed an exponential decrease of the mean bubble concentration with increasing temperature, with a halving for every $10^{\circ} \mathrm{C}$ for bubbles with radii between about $10 \mu \mathrm{m}$ and $150 \mu \mathrm{m}$ at $4 \mathrm{~m}$ depth. Since the transfer function between bubble number concentration and particle number concentration is unknown, one can only speculate what this implies for our observations.

Our measurements focused on sub-micrometer particles. These particles are most likely a consequence of evaporation and production of so-called film drops with radii between about $10 \mathrm{~nm}$ and a few hundred micrometers. Somewhat counter-intuitively, these small droplets (and thus the submicrometer particles) are most likely produced by air bubbles larger than $2 \mathrm{~mm}$ in diameter, whereas air bubbles with a radius smaller than $1 \mathrm{~mm}$ mainly form droplets with a radius in the super-micrometer range (de Leeuw et al., 2011). With our instrumentation, we could only measure air bubbles with $D_{\mathrm{b}}<1140 \mu \mathrm{m}$. Thus, we could not obtain any information regarding the temperature dependence of the bubble size range that was perhaps the most relevant for the particles observed.

\subsection{Effect of oxygen saturation on particle number concentration}

No dependence of the particle number concentration on oxygen saturation between $72 \%$ and $83 \%$ for particles with a $D_{\mathrm{p}}>0.01 \mu \mathrm{m}$ or $D_{\mathrm{p}}>0.25 \mu \mathrm{m}$ was observed. Hultin et al. (2010) did find a relationship between dissolved oxygen (in an oxygen saturation range between $90 \%$ and $107 \%$ ) and sea spray production in the northeast Atlantic Ocean. Hultin et al. (2011) observed an anti-correlation between particle production and dissolved oxygen at shallow water in the Baltic Sea, following the biologically driven diurnal cycle in the water (oxygen saturation range between $90 \%$ and $100 \%$ ).

\subsection{Effect of salinity on particle number concentration}

The influence of salinities between $26 \%$ and $36 \%$ on the shape and magnitude of the median particle number size distributions revealed no clear trend for water temperatures between 6 and $7^{\circ} \mathrm{C}$. A trend of increasing total particle number concentration with increasing salinity was only observed for $T_{\mathrm{w}}$ between -2 and $-1{ }^{\circ} \mathrm{C}$ and $T_{\mathrm{w}}$ between 0 and $1{ }^{\circ} \mathrm{C}$ (both for $D_{\mathrm{p}}>0.01 \mu \mathrm{m}$ ) and for $T_{\mathrm{w}}$ between -1 and $0{ }^{\circ} \mathrm{C}$ $\left(D_{\mathrm{p}}>0.25 \mu \mathrm{m}\right)$. An impact of salinity on particle number size distribution and particle number concentration has been observed in other studies (Mårtensson et al., 2003; Hultin et al., 2011). Mårtensson et al. (2003) compared number size distributions with salinities of $9.3 \%$ and $33 \%$ o. Higher number concentrations for particles with $D_{\mathrm{p}}>0.2 \mu \mathrm{m}$, but a similar shape of the distribution, was measured for the water with higher salinity. Hultin et al. (2011) observed higher particle number concentrations over the whole measurement range for higher salinity ranges (examining real ocean water with salinities about $6 \%$, $7 \%$ and $35 \%$ salinity).

\subsection{Effect of sea water temperature on particle number concentration}

A dependence of primary marine particle number concentration with water temperature has previously been observed by a number of authors (Bowyer et al., 1990; Hultin et al., 2011; Sellegri et al., 2006; Mårtensson et al., 2003). Bowyer et al. (1990) used a $3 \mathrm{~m}$ long white cap simulation tank, in which two waves of collected coastal water broke against each other in the middle of the tank. They observed (similar to our study) a steep decrease of particle number concentration for particles with a $D_{\mathrm{p}}<3 \mu \mathrm{m}$ with slowly increasing water temperature from $0^{\circ} \mathrm{C}$ to $13^{\circ} \mathrm{C}$. For temperatures higher than $13^{\circ} \mathrm{C}$, the particle number concentration remained constant. Mårtensson et al. (2003) observed a decrease of particle number concentration with increasing water temperatures (for the temperatures $-2^{\circ} \mathrm{C}, 5^{\circ} \mathrm{C}$, $15^{\circ} \mathrm{C}$ and $23^{\circ} \mathrm{C}$ ) for particles with $D_{\mathrm{p}}<70 \mathrm{~nm}$. For particles with $D_{\mathrm{p}}>350 \mathrm{~nm}$ an increase of particle number concentration was observed. Sellegri et al. (2006) reported a shift 
of modes from $110 \mathrm{~nm}$ to $85 \mathrm{~nm}$, from $45 \mathrm{~nm}$ to $30 \mathrm{~nm}$ and from $300 \mathrm{~nm}$ to $200 \mathrm{~nm}$, when water temperature decreased from $23^{\circ} \mathrm{C}$ to $4{ }^{\circ} \mathrm{C}$. Both Mårtensson et al. (2003) and Sellegri et al. (2006) used artificial sea water and a sintered glass filter at the bottom of an experimental tank to produce the bubbles. Hultin et al. (2011) observed, during experiments with Baltic Sea water, a decrease of aerosol number concentration in the size range $0.02 \mu \mathrm{m}<D_{\mathrm{p}}<1.8 \mu \mathrm{m}$, when water temperature of $4{ }^{\circ} \mathrm{C}$ changed to $14^{\circ} \mathrm{C}$. The negative correlation of the number concentration with water temperature was observed for all particle sizes. An identical setup to the one used in our experiment was used in that study. We conclude that the observed trend of particle number concentration with water temperature is not due to changes of oxygen saturation. This conclusion is based on the fact that a change in oxygen saturation between $72 \%$ and $83 \%$ for the water temperature range $5-6{ }^{\circ} \mathrm{C}$ and $1-2{ }^{\circ} \mathrm{C}$ did not cause any change in particle number concentration, whereas a change in water temperature within these small intervals did.

Although several studies support our results of a decrease in total particle number concentration with an increase in water temperature (see studies mentioned above), there are some studies indicating the opposite relationship. Monahan and O'Muircheartaigh (1986) demonstrated that for a constant wind speed, an increase in water temperature enlarges the whitecap fraction on the ocean surface. This is important, as the sea spray aerosol production is considered proportional to the whitecap fraction. Jaeglé et al. (2011) compared globally modeled and observed mass concentrations of coarse mode sea salt aerosol (in their study taken to be particles with a radius between 0.3 and $3 \mu \mathrm{m}$ ) and concluded that the modeled bias was improved when introducing an increased sea salt production with increasing water temperature. The increase of whitecap fraction with an increase in surface water temperature can be explained by an increased production of smaller air bubbles with slower terminal rise velocities compared to larger bubbles with an increase in water temperature. Monahan (1985, in Monahan and O'Muircheartaigh, 1986) showed that the time constant characterizing the decay of whitecaps changed inversely with the terminal rise speed of the smaller bubbles. Anguelova et al. (2006) stated that a decrease in viscosity caused by higher water temperatures facilitated wave breaking and as a consequence prolongs the lifetime of a whitecap. Another suggested explanation for observed large-scale increases in whitecap fraction with an increase in water temperature is the difference in the duration of a certain wind speed over different areas. Trade winds, for example, occur over relatively warm waters and persist relatively long so that whitecaps can fully develop, whereas over colder waters the duration of high wind speeds is relatively short (Monahan and O'Muircheartaigh, 1986). During our laboratory experiments, we did indeed produce small areas of whitecaps as a consequence of air bubbles reaching the water surface. However, we did not observe any increase in particle number concentration with an increase in water temperature, as one would expect if the whitecap fraction depends on the sea surface temperature as suggested by Monahan and O'Muircheartaigh (1986) and Jaeglé et al. (2011). One explanation could be that the water surface in the experimental bottle was too limited to allow for an undisturbed whitecap fraction evolution (that wall effects limited the bubble plume and hence the white cap size). On the other hand, no change in the bubble spectrum with temperature was observed either, which is notable as this should be a major cause of the whitecap fraction change with water temperature. Another possible reason for the contradictory results obtained in our study and the ones presented by Jaeglé et al. (2011) could be that the latter focused on coarse mode concentrations of sea salt, whereas the temperature dependence observed in our study was most clear for aerosols with a diameter smaller than $1 \mu \mathrm{m}$. A positive temperature trend could also be explained by the results of Mårtensson et al. (2003), which in contrast to the current study saw increasing aerosol numbers produced at diameters larger than about $350 \mathrm{~nm}$ with increasing temperature (and decreasing numbers for smaller particles in agreement with the current study).

Conducting warming experiments with water sampled at the same time but used on two different days showed particle number concentration differences of up to $97 \%$ (for the same size range and water temperature). The inevitable differences in experimental setup between the different experiments made it difficult to repeat a certain experiment and obtain exactly the same results. However, it cannot be excluded that biological and chemical activity modified the properties of the water during storage which may have affected the particle concentration.

In recent years, it has been shown that organic matter may contribute to a large fraction of the SSA sub-micrometer mass (O’Dowd et al., 2004; Vignati et al., 2010). One possible explanation for the observed change in SSA concentration with temperature is that over time, a depletion of organic compounds from the sea water in the storage tank occurred. Even in the beginning of the twilight period in the Arctic, a certain amount of organic material can be expected. Since the polar night near Kongsfjorden lasts from 25 October to 17 February (Svendsen et al., 2002), our measurements took place in the beginning of the biologically active period.

However, our observations, and especially the sets of mirroring warming/cooling experiments, support that for winter Arctic Ocean seawater, most of the variation in particle number concentration originated from sea water temperature changes and not from a depletion of organic substances from the sea water.

The aerosol emissions were most likely controlled by the physical properties of water (temperature dependent changes in surface tension and viscosity), whereas they were not limited by the amount of organic substances. Our results suggest that the organic fraction of the SSA, under the conditions observed, is not controlling the number concentration itself (within one experiment). This hypothesis needs further 
testing and has to be experimentally explored as other studies have shown a clear effect of organic matter on physical properties of water which may alter air bubble generation. For example, Nägeli and Schanz (1991) reported that surface tension was reduced by phytoplankton exudates and Lion and Leckie (1981) theoretically described the decrease of surface tension caused by surface-active organics. An impact of organics on bubble properties was determined by Garrett (1967). A stabilization of air bubbles on the air-sea interface due to surface-active substances scavenged by the air bubble while rising to the water surface was observed. However, with our current data, we cannot address the role of surfactants in SSA emissions for winter Arctic Ocean conditions. These somewhat contradicting results call for further studies on the role of organic matter on particles emissions from the oceans.

\section{Future implication}

The observed trend of decreasing SSA production with increasing water temperature may have large implications for the climate in the Arctic region. The diminishing sea ice will result in a decreased surface albedo and contribute to a positive feedback of the Arctic warming. At the same time, larger areas of ice-free ocean will provide large areas of potential SSA emissions, which in turn can act as a negative feedback by increasing aerosol scattering and by modifying cloud microphysical properties providing additional CCN (cf. Struthers et al., 2011). On the other hand, with increasing sea water temperature and as shown in this study, the sea spray source strength might decrease and thus weaken the negative feedback of SSA on Arctic climate. Another important factor influencing the sea spray aerosol emissions is the wind speed. In order to answer questions about how changes in SSA emissions influence the future Arctic climate, it is important to consider all of the above-mentioned factors. To summarize, there are a number of potential feedback processes between a future changing climate, changes in surface albedo and changes in sea spray production, for example:

- Increasing (decreasing) water temperature will decrease (increase) sea spray emissions due to changes in the physical properties of water (present study; Bowyer et al., 1990; Hultin et al., 2011).

- Increasing (decreasing) wind velocities will result in increased (decreased) sea spray emissions (Lovett, 1978; Nilsson et al., 2001; Geever et al., 2005).

- Increasing (decreasing) water temperature will increase (decrease) whitecap fraction and increase (decrease) sea spray emissions (Monahan and O'Muircheartaigh, 1986).
- Increasing (decreasing) wind speed will increase (decrease) whitecap fraction and thereby increase (decrease) albedo (Monahan and O'Muircheartaigh, 1986).

- Increasing (decreasing) temperature will decrease (increase) sea ice cover and increase (decrease) sea salt emissions (e.g., Nilsson et al., 2001; Struthers et al., 2011).

- Increasing (decreasing) temperature will decrease (increase) sea ice cover and decrease (increase) surface albedo.

Struthers et al. (2011), however, indicated that the impact of future changes in wind speed on the sea salt aerosol production over the Arctic Ocean was small compared to those associated with changes in sea ice coverage and sea surface temperature. All in all, the magnitude and interplay between the decrease of sea ice coverage, the increasing sea water temperature, changes in wind speed and the possible accompanied change in whitecap coverage should be addressed in large-scale model studies, where changes in meteorology, ocean characteristics and marine aerosol emissions all are represented in a consistent manner. An updated sea spray aerosol emission parameterization, which better represents the effects of low sea water temperatures on the SSA emission strength, would be useful to develop for these types of studies.

\section{Summary and conclusions}

The influence of water temperature, salinity, and oxygen saturation on sea spray aerosol emissions from winter Arctic Ocean sea water was studied by means of laboratory experiments at Ny-Ålesund, Svalbard. In ambient conditions, wind speed is the dominant physical parameter determining sea spray production (e.g., Nilsson et al., 2001). Tank experiments, such as those presented in this study, remove any influence of wind speed. The results show that in the absence of wind, sea water temperature is the most important of the studied parameters controlling the magnitude of sea spray aerosol emissions. During the bubble bursting laboratory experiments and for the measured water temperature range between $9^{\circ} \mathrm{C}$ and $-2^{\circ} \mathrm{C}$, particle number concentrations were increasing with a decrease in water temperature. The largest change of magnitude was observed between $2{ }^{\circ} \mathrm{C}$ and $5^{\circ} \mathrm{C}$ where the rate of change was between $22 \%$ and $33 \%$ per $1{ }^{\circ} \mathrm{C}$ for particles $D_{\mathrm{p}}>0.01 \mu \mathrm{m}$ and between $14 \%$ and $27 \%$ for particles $D_{\mathrm{p}}>0.25 \mu \mathrm{m}$. No clear relation was found between sea spray aerosol concentrations and salinity. In addition, for the limited oxygen range encountered, oxygen saturation changes did not influence particle number concentration. The dependence of sea spray aerosol emissions on water temperature was reflected in the magnitude of aerosol concentrations in various modes, whereas the aerosol 
size distribution shape remained unchanged. This is consistent with the fact that the particle number size distribution shape exhibited a conservative behavior for all conducted experiments. Further research is needed to clarify the potential effect of organic matter on SSA concentrations and to put in perspective to the observed water temperature effect found in this study. Furthermore, implementation of our results into large-scale climate models would be useful to give a more complete picture of the feedback processes occurring in the Arctic region.

Acknowledgements. We would like to thank the Kings Bay Marine Laboratory, Norwegian Polar Institute (NPI) staff and Kai Rosman for their support during the field experiment at $\mathrm{Ny}$-Ålesund. The Norwegian Meteorological Institute is acknowledged for providing the meteorological data. This work was funded by the Swedish Research Council FORMAS. The European Centre for Arctic Environmental Research in Ny-Ålesund (ARCFAC V) is acknowledged for support (ARCFAC-026129-2009-39) and the Swedish Polar Research Secretariat for providing field equipment.

Edited by: A. Pszenny

\section{References}

ACIA: Arctic Climate Impact Assessment, chap. 2, p. 23, Cambridge University Press, New York, USA, 2005.

Anguelova, M. D., Webster, F.: Whitecap coverage from satellite measurements: A first step toward modeling the variability of oceanic whitecaps, J. Geophys. Res.-Oceans, 111, C03017, doi:10.1029/2005JC003158, 2006.

Bekryaev, R. V., Polyakov, I. V., and Alexeev, V. A.: Role of polar amplification in long-term surface air temperature variations and modern Arctic warming, J. Climate., 23, 3888-3906, doi:10.1175/2010JCLI3297.1, 2010.

Bowyer, P. A.: Video measurements of near-surface bubble spectra, J. Geophys. Res.-Oceans, 106, 14179-14190, doi:10.1029/2000JC000208, 2001.

Bowyer, P. A., Woolf, D. K., and Monahan, E. C.: Temperature dependence of the charge and aerosol production associated with a breaking wave in a whitecap simulation tank, J. Geophys. Res.Oceans, 95, 5313-5319, doi:10.1029/JC095iC04p05313, 1990.

Boyer, T., Conkright, M. E., and Levitus, S.: Seasonal variability of dissolved oxygen, percent oxygen saturation, and apparent oxygen

utilization in the Atlantic and Pacific Oceans, Deep-Sea Res.(1 Oceanogr. Res. Pap.), 46, 1593-1613, doi:10.1016/S09670637(99)00021-7, 1999.

Carslaw, K. S., Boucher, O., Spracklen, D. V., Mann, G. W., Rae, J. G. L., Woodward, S., and Kulmala, M.: A review of natural aerosol interactions and feedbacks within the Earth system, Atmos. Chem. Phys., 10, 1701-1737, doi:10.5194/acp-10-17012010, 2010.

Clarke, A. D., Owens, S. R., and Zhou, J.: An ultrafine sea-salt flux from breaking waves: implications for cloud condensation nuclei in the remote marine atmosphere, J. Geophys. Res.-Atmos., 111, D06202, doi:10.1029/2005JD006565, 2006.
Comiso, J. C., Parkinson, C. L., Gersten, R., and Stock, L.: Accelerated decline in the Arctic sea ice cover, Geophys. Res. Lett., 35, L01703, doi:10.1029/2007GL031972, 2008.

de Leeuw, G., Andreas, E. L., Anguelova, M. D., Fairall, C. W., Lewis, E. R., O'Dowd, C., Schulz, M., and Schwartz, S. E.: Production flux of sea spray aerosol, Rev. Geophys., 49, RG2001, doi:10.1029/2010RG000349, 2011.

Eastwood, S., Le Borgne, P., Péré, S., and Poulter, D.: Diurnal variability in sea surface temperature in the Arctic, Remote. Sens. Environ., 115, 2594-2602, doi:10.1016/j.rse.2011.05.015, 2011.

Falkner, K. K., Steele, M., Woodgate, R. A., Swift, J. H., Aagaard, K., and Morison, J.: Dissolved oxygen extrema in the Arctic Ocean halocline from the North Pole to the Lincoln Sea, Deep-Sea Res.(1 Oceanogr. Res. Pap.), 52, 1138-1154, doi:10.1016/j.dsr.2005.01.007, 2005.

Fuentes, E., Coe, H., Green, D., de Leeuw, G., and McFiggans, G.: Laboratory-generated primary marine aerosol via bubblebursting and atomization, Atmos. Meas. Tech., 3, 141-162, doi:10.5194/amt-3-141-2010, 2010.

Garrett, W. D.: Stabilization of air bubbles at the air-sea interface by surface-active material, Deep-Sea Res., 14, 661-672, doi:10.1016/S0011-7471(67)80004-4, 1967.

Geever, M., O’Dowd, C. D., van Ekeren, S., Flanagan, R., Nilsson, E. D., de Leeuw, G., and Rannik, Ü.: Submicron sea spray fluxes, Geophys. Res. Lett., 32, L15810, doi:10.1029/2005GL023081, 2005.

Holland, M. M. and Bitz, C. M.: Polar amplification of climate change in coupled models, Clim. Dynam., 21, 221-232, doi:10.1007/s00382-003-0332-6, 2003.

Hop, H., Falk-Petersen, S., Svendsen, H., Kwasniewski, S., Pavlov, V., Pavlova, O., and Søreide, J. E.: Physical and biological characteristics of the pelagic system across Fram Strait to Kongsfjorden, Prog. Oceanogr., 71, 182-231, doi:10.1016/j.pocean.2006.09.007, 2006.

Hultin, K. A. H., Nilsson, E. D., Krejci, R., Mårtensson, E. M., Ehn, M., Hagström, Å., and de Leeuw, G.: In situ laboratory sea spray production during the marine aerosol production 2006 cruise on the Northeastern Atlantic Ocean, J. Geophys. Res.-Atmos., 115, D06201, doi:10.1029/2009JD012522, 2010.

Hultin, K. A. H., Krejci, R., Pinhassi, J., Gomez-Consarnau, L., Mårtensson, E. M., Hagström, Å., and Nilsson, E. D.: Aerosol and bacterial emissions from Baltic seawater, Atmos. Res., 99, 1-14, doi:10.1016/j.atmosres.2010.08.018, 2011.

Hwang, P. A., Poon, Y. K., and Wu, J.: Temperature effects on generation and entrainment of bubbles induced by a water jet, J. Phys. Oceano., 21, 1602-1605, doi:10.1175/15200485(1991)021<1602:TEOGAE > 2.0.CO;2, 1991.

Ito, H. and Kudoh, S.: Characteristics of water in Kongsfjorden, Proc. NIPR Symp. Polar Meteorol. Glaciol., 11, 211-232, 1997.

Jaeglé, L., Quinn, P. K., Bates, T. S., Alexander, B., and Lin, J.-T.: Global distribution of sea salt aerosols: new constraints from in situ and remote sensing observations, Atmos. Chem. Phys., 11, 3137-3157, doi:10.5194/acp-11-3137-2011, 2011.

Johannessen, O. M., Shalina, E. V., and Miles, M. W.: Satellite evidence for an Arctic sea ice cover in transformation, Science, 286, 1937-1939, doi:10.1126/science.286.5446.1937, 1999.

Kester, D. R. and Pytkowicz, R. M.: Oxygen Saturation in the Surface Waters of the Northeast Pacific Ocean, J. Geophys. Res., 73, 5421-5424, doi:10.1029/JB073i016p05421, 1968. 
Leifer, I. and de Leeuw, G.: Bubbles generated from windsteepened breaking waves: 1. bubble plume bubbles, J. Geophys. Res.-Oceans, 111, C06020, doi:10.1029/2004JC002673, 2006.

Leifer, I., Patro, R. K., and Bowyer, P.: A study on the temperature variation of rise velocity for large clean bubbles, J. Atmos. Ocean. Tech., 17, 1392-1402, doi:10.1175/15200426(2000)017<1392:ASOTTV>2.0.CO;2, 2000.

Leifer, I., de Leeuw, G., and Cohen, L. H.: Optical measurement of bubbles: system design and application, J. Atmos. Ocean. Tech., 20, 1317-1332, doi:10.1175/15200426(2003)020<1317:OMOBSD>2.0.CO;2, 2003.

Lemke, P., Ren, J., Alley, R. B., Allison, I., Carrasco, J., Flato, G., Fujii, Y., Kaser, G., Mote, P., Thomas, R. H., and Zhang, T.: Observations: Changes in Snow, Ice and Frozen Ground, Climate Change 2007: The Physical Science Basis. Contribution of Working Group I to the Fourth Assessment Report of the Intergovernmental Panel on Climate Change, Cambridge University Press, Cambridge, New York, 2007.

Lewis, E. R. and Schwartz, S. E.: Sea Salt Aerosol Production: Mechanisms, Methods, Measurements, and Models, Geophysical Monograph Series, American Geophysical Union, Washington, DC, 2004.

Lion, L. W. and Leckie, J. O.: The biogeochemistry of the air-sea interface, Annu. Rev. Earth Pl. Sc., 9, 449-486, doi:10.1146/annurev.ea.09.050181.002313, 1981.

Lovett, R. F.: Quantitative measurement of airborne sea-salt in the North Atlantic, Tellus, 30, 358-363, doi:10.1111/j.21533490.1978.tb00851.x, 1978.

Lu, J. and Cai, M.: Quantifying contributions to polar warming amplification in an idealized coupled general circulation model, Clim. Dynam., 34, 669-687, doi:10.1007/s00382-009-0673-x, 2010.

Ma, X., von Salzen, K., and Li, J.: Modelling sea salt aerosol and its direct and indirect effects on climate, Atmos. Chem. Phys., 8, 1311-1327, doi:10.5194/acp-8-1311-2008, 2008.

Manabe, S. and Stouffer, R. J.: Sensitivity of a global climate model to an increase of $\mathrm{CO}_{2}$ concentration in the atmosphere, J. Geophys. Res.-Oceans, 85, 5529-5554, doi:10.1029/JC085iC10p05529, 1980.

Markus, T., Stroeve, J. C., and Miller, J.: Recent changes in Arctic sea ice melt onset, freezeup, and melt season length, J. Geophys. Res.-Oceans, 114, C12024, doi:10.1029/2009JC005436, 2009.

Mårtensson, E. M., Nilsson, E. D., de Leeuw, G., Cohen, L. H., and Hansson, H.-C.: Laboratory simulations and parameterization of the primary marine aerosol production, J. Geophys. Res.-Atmos., 108, 4297, doi:10.1029/2002JD002263, 2003.

Miller, G. H., Alley, R. B., Brigham-Grette, J., Fitzpatrick, J. J., Polyak, L., Serreze, M. C., and White, J. W. C.: Arctic amplification: can the past constrain the future?, Quaternary Sci. Rev., 29, 1779-1790, doi:10.1016/j.quascirev.2010.02.008, 2010.

Monahan, E. C.: The ocean as a source for atmospheric particles, Proceedings of the NATO Advanced Study Institute Conference on the Role of Air-Sea Exchange in Geochemical Cycling, Dordrecht: Reidel, 1985.

Monahan, E. C. and O'Muircheartaigh, I. G.: Whitecaps and the passive remote sensing of the ocean surface, Int. J. Remote Sens., 7, 627-642, doi:10.1080/01431168608954716, 1986.

Mopper, K., Zhou, X., Kieber, R. J., Kieber, D. J., Sikorski, R. J., and Jones, R. D.: Photochemical degradation of dissolved organic-carbon and its impact on the oceanic carbon-cycle, $\mathrm{Na}-$ ture, 353, 60-62, doi:10.1038/353060a0, 1991.

Nägeli, A. and Schanz, F.: The influence of extracellular algal products on the surface-tension of water, Int. Rev. Ges. Hydrobio., 76, 89-103, doi:10.1002/iroh.19910760110, 1991.

Nilsson, E. D., Rannik, U., Swietlicki, E., Leck, C., Aalto, P. P., Zhou, J., and Norman, M.: Turbulent aerosol fluxes over the Arctic Ocean. 2. Wind-driven sources from the sea, J. Geophys. Res.Atmos., 106, 32139-32154, doi:10.1029/2000JD900747, 2001.

Nuth, C., Moholdt, G., Kohler, J., Hagen, J. O., and Kääb, A.: Svalbard glacier elevation changes and contribution to sea level rise, J. Geophys. Res.-Earth., 115, F01008, doi:10.1029/2008JF001223, 2010.

O’Dowd, C. D., Smith, M. H., Consterdine, I. E., and Lowe, J. A.: Marine aerosol, sea-salt, and the marine sulphur cycle: a short review, Atmos. Environ., 31, 73-80, 1997.

O’Dowd, C. D., Facchini, M. C., Cavalli, F., Ceburnis, D., Mircea, M., Decesari, S., Fuzzi, S., Yoon, Y. J., and Putaud, J.-P.: Biogenically driven organic contribution to marine aerosol, Nature, 431, 676-680, doi:10.1038/nature02959, 2004.

Ovadnevaite, J., Ceburnis, D., Martucci, G., Bialek, J., Monahan, C., Rinaldi, M., Facchini, M. C., Berresheim, H., Worsnop, D. R., and O'Dowd, C.: Primary marine organic aerosol: a dichotomy of low hygroscopicity and high CCN activity, Geophys. Res. Lett., 38, L21806, doi:10.1029/2011GL048869, 2011.

Parkinson, C. L. and Cavalieri, D. J.: Arctic sea ice variability and trends, 1979-2006, J. Geophys. Res.-Oceans, 113, C07003, doi:10.1029/2007JC004558, 2008.

Piehl Harms, A. A., Tverberg, V., and Svendsen, H.: Physical Qualification and Quantification of the Water Masses in the Kongsfjorden-Krossfjorden System Cross Section, in: Proceedings Paper, Oceans 07, IEEE, Aberdeen, 061215-086, doi:10.1109/OCEANSE.2007.4302332, 2007.

Polyakov, I., Timokhov, L., Dmitrenko, I., Ivanov, V., Simmons, H., Beszczynska-Möller, A., Dickson, R., Fahrbach, E., Fortier, L., Gascard, J.-C., Hölemann, J., Holliday, N. P., Hansen, E., Mauritzen, C., Piechura, J., Pickart, R., Schauer, U., Steele, M., and Walczowski, W.: Observational Program Tracks Arctic Ocean Transition to a Warmer State, EOS, Transactions American Geophysical Union, 88, 398-399, doi:10.1029/2007EO400002, 2007.

Sellegri, K., O’Dowd, C. D., Yoon, Y. J., Jennings, S. G., and de Leeuw, G.: Surfactants and submicron sea spray generation, J. Geophys. Res-Atmos., 111, D22215, doi:10.1029/2005JD006658, 2006.

Slauenwhite, D. E. and Johnson, B. D.: Bubble shattering: differences in bubble formation in fresh water and seawater, J. Geophys. Res.-Oceans, 104, 3265-3275, doi:10.1029/1998JC900064, 1999.

Steele, M., Ermold, W., and Zhang, J.: Arctic Ocean surface warming trends over the past 100 years, Geophys. Res. Lett., 35, L02614, doi:10.1029/2007GL031651, 2008.

Struthers, H., Ekman, A. M. L., Glantz, P., Iversen, T., Kirkevåg, A., Mårtensson, E. M., Seland, Ø., and Nilsson, E. D.: The effect of sea ice loss on sea salt aerosol concentrations and the radiative balance in the Arctic, Atmos. Chem. Phys., 11, 3459-3477, doi:10.5194/acp-11-3459-2011, 2011.

Svendsen, H., Beszczynska-Möller, A., Hagen, J. O., Lefauconnier, B., Tverberg, V., Gerland, S., Ørbøk, J. B., Bischof, 
K., Papucci, C., Zajaczkowski, M., Azzolini, R., Bruland, O., Wiencke, C., Winther, J.-G., and Dallmann, W.: The physical environment of Kongsfjorden-Krossfjorden, an Arctic fjord system in Svalbard, Polar Res., 21, 133-166, doi:10.1111/j.17518369.2002.tb00072.x, 2002.

Textor, C., Schulz, M., Guibert, S., Kinne, S., Balkanski, Y., Bauer, S., Berntsen, T., Berglen, T., Boucher, O., Chin, M., Dentener, F., Diehl, T., Easter, R., Feichter, H., Fillmore, D., Ghan, S., Ginoux, P., Gong, S., Grini, A., Hendricks, J., Horowitz, L., Huang, P., Isaksen, I., Iversen, I., Kloster, S., Koch, D., Kirkevåg, A., Kristjansson, J. E., Krol, M., Lauer, A., Lamarque, J. F., Liu, X., Montanaro, V., Myhre, G., Penner, J., Pitari, G., Reddy, S., Seland, Ø., Stier, P., Takemura, T., and Tie, X.: Analysis and quantification of the diversities of aerosol life cycles within AeroCom, Atmos. Chem. Phys., 6, 1777-1813, doi:10.5194/acp-6-1777-2006, 2006.

Thorpe, S. A., Bowyer, P., and Woolf, D. K.: Some factors affecting the size distributions of oceanic bubbles, J. Phys. Oceanogr., 22, 382-389, doi:10.1175/15200485(1992)022<0382:SFATSD>2.0.CO;2, 1992.

Tremblay, J.-E., Bélanger, S., Barber, D. G., Asplin, M., Martin, J., Darnis, G., Fortier, L., Gratton, Y., Link, H., Archambault, P., Sallon, A., Michel, C., Williams, W. J., Philippe, B., and Gosselin, M.: Climate forcing multiplies biological productivity in the coastal Arctic Ocean, Geophys. Res. Lett., 38, L18604, doi:10.1029/2011GL048825, 2011.
Vignati, E., Facchini, M. C., Rinaldi, M., Scannell, C., Ceburnis, D., Sciare, J., Kanakidou, M., Myriokefalitakis, S., Dentener, F., and O'Dowd, C. D.: Global scale emission and distribution of seaspray aerosol: sea-salt and organic enrichment, Atmos. Environ. 44, 670-677, doi:10.1016/j.atmosenv.2009.11.013, 2010.

Wang, J.: Effects of spatial and temporal variations in aerosol properties on mean cloud albedo, J. Geophys. Res.-Atmos., 112, D16201, doi:10.1029/2007JD008565, 2007.

Wang, M. and Overland, J. E.: A sea ice free summer Arctic within 30 years?, Geophys. Res. Lett., 36, L07502, doi:10.1029/2009GL037820, 2009.

Wassmann, P. and Reigstad, M.: Future Arctic Ocean seasonal ice zones and implications for pelagic-benthic coupling, Oceanography, 24, 220-231, 2011.

Winton, M.: Amplified Arctic climate change: what does surface albedo feedback have to do with it?, Geophys. Res. Lett., 33, L03701, doi:10.1029/2005GL025244, 2006.

Zábori, J., Krejci, R., Ström, J., Ekman, A. M. L., Vaattovaara, P., Mårtensson, E. M., and Nilsson, E. D.: Comparison between summertime and wintertime Arctic Ocean primary marine aerosol properties, in preparation, 2012.

Zhang, J.: Warming of the arctic ice-ocean system is faster than the global average since the 1960s, Geophys. Res. Lett., 32, L19602, doi:10.1029/2005GL024216, 2005. 